\title{
Kognitivne karte i post-konfliktno stanje: slika vlastitoga kraja učenika osnovne škole Jabukovac (Banovina)
}

\author{
Laura Šakaja
}

\begin{abstract}
Članak se bavi kognitivnim kartama starijih osnovnoškolaca (od petog do osmog razreda) u jednom od post-konfliktnih područja Hrvatske. Koristi se kvantitativna analiza karata crtanih rukom ispitanika i kvalitativna analiza tekstualnih odgovora na anketna pitanja. Na osnovi toga dolazi se do zaključaka o nizu faktora koji utječu na distorzije i selektivnost kognitivnih karata. Rekonstruira se neformalno geografsko znanje o vlastitom kraju i parametri preko kojih se on doživljava.

Ključne riječi: kognitivne karte, post-konfliktno stanje, distorzije, neformalna geografija, Banovina
\end{abstract}

\section{Cognitive Maps in a Post-Conflict Situation: the Image of One's Own Region among Pupils in Jabukovac Elementary School (Ba- novina)}

The paper deals with cognitive maps among older elementary school pupils (in grades $5-8$ ) in one of the post-conflict regions of Croatia. The methodology involved quantitative analysis of the respondents' hand-drawn maps and qualitative analysis of textual answers to questionnaire items. This led to conclusions in regard to a series of factors that influence the distortions and the selectivity of cognitive maps. A reconstruction was made of informal geographical knowledge of one's own region, as well as of the parameters through which the home region is experienced. Banovina

Key words: cognitive maps, post-conflict situation, distortions, informal geography,

\section{UVOD}

Poznavati vlastitu geografsku okolinu znači imati neku vrstu akumuliranoga geografskoga znanja o njoj. To je znanje uvijek subjektivno. Ono je selektivno, jer ljudi obično pamte samo određene elemente - istaknute, objektivno i/ili subjektivno važne, itd. Ono je $\mathrm{i}$ iskrivljeno, jer se euklidska struktura prostora i njegova stvarna konfiguracija prelamaju u svijesti kroz neeuklidske čimbenike (putanje kojima se krećemo, vrijeme koje trošimo na put, mjesta koje često posjećujemo ili uz koja smo sentimentalno vezani i sl.) i pritom doživljavaju deformacije, a njihovi se pojedini elementi naglašavaju ili ignoriraju, saži- 
mlju se, produljuju ili rotiraju. Upravo nepodudarnost strukture objektivnoga prostora i subjektivnih predodžbi o njemu inspirirala je sada već četrdesetogodišnju tradiciju proučavanja kognitivnih odnosno mentalnih karata. "Kognitivna karta je mentalna reprezentacija izvanjske okoline" (Tverski, 2000, 25). To je termin koji se odnosi na znanje pojedinca o prostornim odnosima (Kitchin i Blades, 2002, 1). Otkako je taj termin prvi upotrijebio Tolman 1948. godine, pojavilo se mnoštvo sličnih: kognitivna shema, kognitivni prostor, slike prostora, mentalne reprezentacije itd.

U geografiji se uz termin "kognitivna karta" najčešće rabi termin "mentalna karta". On se u nizu slučajeva upotrebljava kao sinonim terminu kognitivna karta (npr. Downs, 1981, Bailly, McCabe i Saarinen, 1995). Često se, ipak, termin mentalna karta koristi u duhu u kojem je prvi put u geografiji bio predstavljen u istraživanjima Goulda i Whitea, tj. označava diferenciranu mentalnu sliku prostora kojega dijelovi evaluiraju s gledišta poželjnosti ili nepoželjnosti za život (Gould i White, 1974). I kada se shvaća šire, čini se da se u geografskoj literaturi termin "mentalna karta" u prvome redu veže uza stavove, preferencije, vrijednosti i vrednovanja pojedinaca i grupa (v. npr. Tuan, 1975). Termin "kognitivna karta", s druge strane, u prvome se redu bavi konfiguracijom i strukturom prostora u mentalnim predodžbama, procjenom relativnih lokacija pojedinih mjesta, percepcijom putanja, udaljenosti i pravaca, drugim riječima - psihološkom transformacijom informacije o međusobnim odnosima i atributima fenomena u čovjekovom svakodnevnom prostornom okruženju (Downs i Stea, 1973). I kada se bave mišljenjima i osjećajima ljudi, istraživači kognitivnih karata u pravilu informaciju o njima traže u reprezentacijama prostora i prostornih odnosa (o tome v. Kitchin i Blades, 2002, 2-3).

Dosadašnja su istraživanja kognitivnih karata donijela mnogo zanimljivih rezultata o karakteru deformacija na kognitivnim kartama. Dokazano je, na primjer, da se na kognitivnim kartama krivine izravnavaju, a kutovi shematiziraju na $90^{\circ}$, da se oblici pamte kao simetričniji nego što su u stvarnosti, kratke se udaljenosti precjenjuju u odnosu na duge, sama procjena udaljenosti ovisi o broju prepreka, križanja, skretanja koje se sreću na putu, itd., itd. (v. Tverski, 2000, Pacione, 1978). Ipak, zbog fragmentarnosti istraživanja kognitivnih karata, a ponekad i proturječnih rezultata različitih istraživanja (o tome v. Ewing, 1981), "dosad je učinjen relativno neznatan napredak u razvijanju jedinstvene teorije kognitivnoga kartiranja koja bi mogla efektivno inkorporirati sve istraživačke nalaze" (Kitchin i Blades, 2002, 3).

\section{ISTRAŽIVAČKI OKVIR}

U ovome ćemo radu analizirati kognitivne karte učenika starijih razreda osnovne škole u selu Jabukovac. Analiza tih kognitivnih karata zasnovana je na prostornim reprezentacijama vlastite okoline, to jest na kartama-skicama vlastitoga kraja što su ih vlastitom rukom crtali ispitanici, te na njihovim odgovorima na pitanja vezana uz prostor njihova kraja.

Istraživanje je imalo je nekoliko ciljeva:

- pridonijeti akumulaciji znanstvenoga znanja o kognitivnim kartama;

- barem djelomično popuniti prazninu u geografskom istraživanju kognitivnih karata u Hrvatskoj (na tu je temu u Hrvatskoj dosad objavljen samo jedan rad, i to s područja psihologije; v. Ajduković i Bistrović, 1987); 
- proučavanjem kognitivnih karata učenika i učenica od jedanaest do četrnaest godina, koji žive u bivšem UNPA području Hrvatske, istražiti mogući utjecaj post-konfliktnoga stanja na percepciju prostora od strane djece.

Tijekom istraživanja nastojalo se odgovoriti na slijedeća pitanja: Kako se u dječjoj percepciji izobličuje struktura prostora? Kako djeca percipiraju udaljenosti i pravce? Koji su elementi geografske sredine za njih važni, a koji se zanemaruju? Śto se pamti i služi kao orijentir, a što se zaboravlja? Kako se vrednuju pojedini aspekti vlastite životne sredine? Mogu li se u kognitivnim kartama prostora prepoznati tragovi krvavoga konflikta koji se na tome prostoru nedavno odvijao?

Istraživanje je obuhvaćalo područje koje teritorijalno pokriva Osnovna škola "Jabukovac" (Sl. 1). To područje ulazi u sjeverni dio Banovine, a administrativno pripada gradu Petrinji (samo par sela ulazi u administrativno područje grada Gline). Prepričana u nekoliko

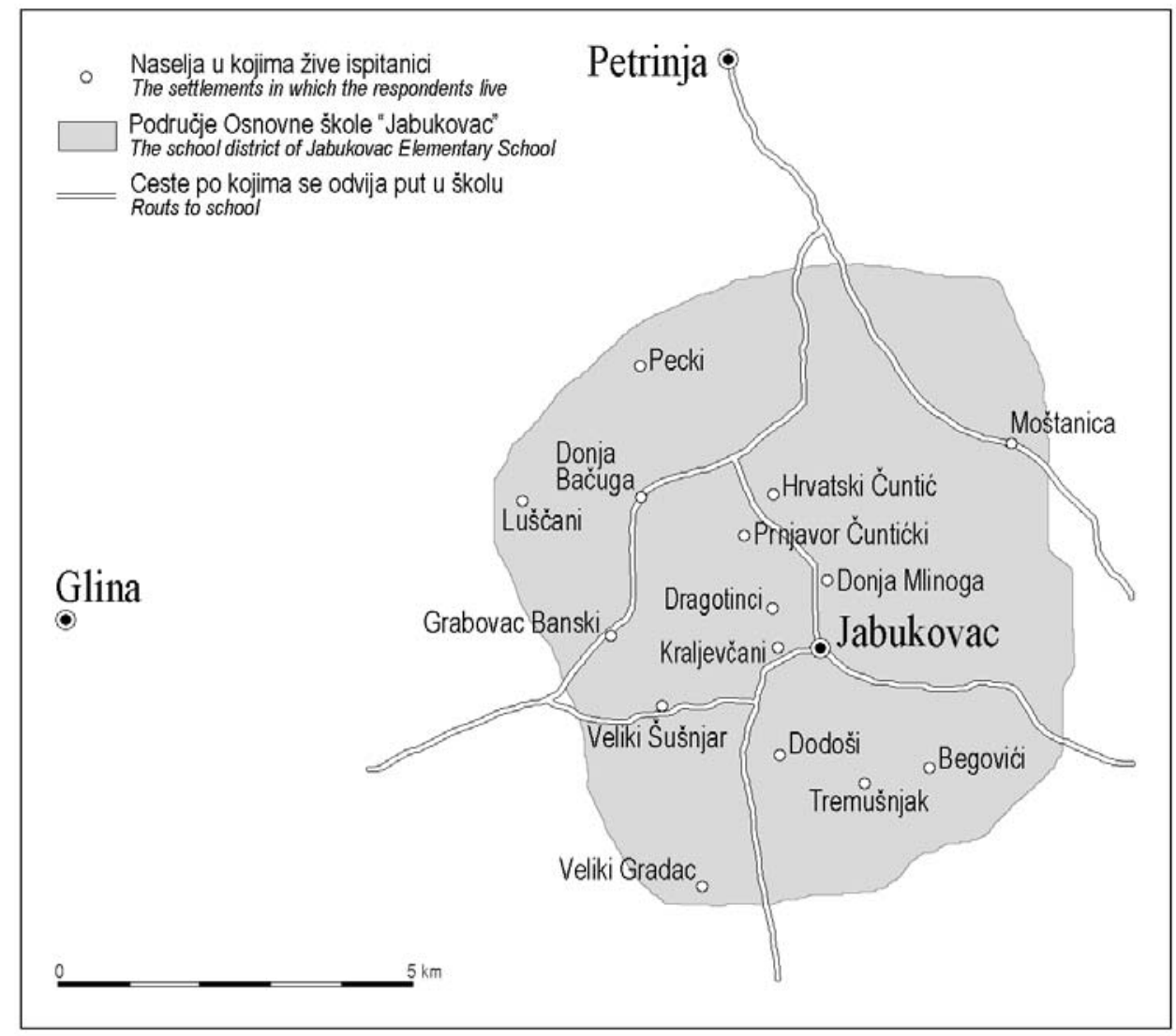

S1. 1. Područje istraživanja

Fig. 1 The research area 
rečenica - povijest kraja posljednjih 14 godina izgleda ovako. Poslije prvih višestranačkih izbora 1990, početkom 1991. godine počinje, uz izravnu pomoć JNA u Hrvatskoj, srpska oružana pobuna te Srbi u Hrvatskoj donose niz odluka s ciljem da se politički i teritorijalno izdvoje iz hrvatske države. Na područje Banovine srpska se pobuna širi tijekom travnja 1991. te je uslijed toga većina lokalnih Hrvata bila prisiljena napustiti svoje domove. Početkom 1992. godine Vijeće sigurnosti UN-a uspostavlja mandat UNPROFOR-a i četiri UNPA zone (zaštićeno područje UN-a), uključujući i UNPA zonu Sjever u koju ulazi i Banovina. Ta su se područje četiri godine nalazila pod upravom i zaštitom UN-a, i tek su nakon vojne operacije "Oluja" (kolovoz 1995) integrirana u pravno-politički sustav Hrvatske. Time s područja Petrinje započinje i povratak više od 13.000 prognanih Hrvata (Živić, 2000, 196-197, 200). Istovremeno, bivše UNPA područje Sjever (kao i područje Jug) napuštaju Srbi. S područja Petrinje Hrvatsku je napustilo 14.972 Srba, tj. 93,8\% srpskog stanovništva (Živić, 2000, 225). Od njih se do kraja 2003. godine vratilo $5.602{ }^{1}$. U ovaj su kraj, kao i u druge dijelove Hrvatske, doselili Hrvati prognani iz BiH, Vojvodine i s Kosova. Dio njih naselio se u sela u kojima je prije Domovinskoga rata srpsko stanovništvo činilo većinu te je time donekle promijenjena prijeratna etnička struktura naselja.

Turbulentna politička zbivanja u velikoj su se mjeri odrazila na broju stanovnika i demografskoj strukturi ovoga područja. I prije rata depopulacijsko, danas ovo područje bilježi

Tab.1. Spolna, dobna i narodnosna struktura ispitanika

Tab. 1 The gender, age and ethnic structure of respondents

\begin{tabular}{|c|c|c|}
\hline \multicolumn{3}{|c|}{ Spolna struktura } \\
\hline Spol & Broj & $\%$ \\
\hline Djevojčice & 23 & 47,9 \\
\hline Dječaci & 25 & 52,1 \\
\hline Svega & 48 & 100 \\
\hline \multicolumn{3}{|c|}{ Dobna struktura } \\
\hline Godine & Broj & $\%$ \\
\hline 11 & 12 & 25,0 \\
\hline 12 & 10 & 20,8 \\
\hline 13 & 14 & 29,2 \\
\hline 14 & 11 & 22,9 \\
\hline 15 & 1 & 2,1 \\
\hline Svega & 48 & 100 \\
\hline \multicolumn{3}{|c|}{ Narodnosna struktura } \\
\hline Narodnost & Broj & $\%$ \\
\hline Hrvati & 21 & 43,8 \\
\hline Srbi & 27 & 56,3 \\
\hline Svega & 48 & 100 \\
\hline
\end{tabular}


znatan pad stanovništva te izrazito visok udio staroga stanovništva u populaciji (Mišetić, 2002). Uslijed smanjenja broja stanovnika i visokog udjela osoba iznad 50 godina među srpskim povratnicima - drastično je smanjen i broj djece osnovnoškolskoga uzrasta. Stoga na području na kojem su prije rata svoju djelatnost obavljale tri osnovne škole s ukupno oko 1.000 učenika danas radi samo jedna osnovna škola u Jabukovcu s ukupno oko 100 učenika.

Naše istraživanje obuhvatilo je 48 učenika te škole, odnosno sve učenike 5, 6, 7. i 8. razreda koji su bili prisutni na dan istraživanja ${ }^{2}$. Iz istraživanja su isključeni učenici nižih razreda jer se - u skladu s Piagetovom teorijom o fazama djetetova razvoja - dob ispod 11 godina za naše istraživanje činila neprikladnom. Naime, prema teoriji koju je Piaget dokazao mnoštvom eksperimenata, tek se u dobi 11-12 godina završava period takozvane konkretne operacionalizacije (concrete operational period) i započinje period formalne operacionalizacije (formal operational period), što znači da do te dobi dijete potpuno ovladava sposobnošću da razumije metrička svojstva udaljenosti, duljine i površine, a njegova prostorna spoznaja ne ovisi više isključivo o interakciji s realnim objektima, nego se počinje razvijati i sposobnost razumijevanja prostora preko apstraktnih mentalnih konstrukcija, odnosno sposobnost organiziranja prostornih informacija u kognitivne slike (Piaget i Inhelder, 1967).

Kao što vidimo iz Tablice 1, među anketiranima je približno isti broj dječaka i djevojčica, uglavnom u dobi od 11-14 godina. Narodnosna struktura anketiranih sastavljena je od 43,8\% Hrvata i 56,3\% Srba. Gotovo su svi učenici srpske narodnosti, s izuzetkom jednoga, rođeni u regiji proučavanja, dok je među učenicima hrvatske narodnosti znatno više doseljenih: u proučavanoj regiji rođeno je tek 47,6\%, a 38,3 \% svih ispitanika-Hrvata činili su mlađi članovi obitelji prognanika doseljenih iz BiH i Vojvodine (v. Tab.2).

Među ispitanicima nema niti jednoga djeteta koje ne bi imalo iskustvo izbjeglištva ili prognanstva - koje je trajalo od minimalno dvije do maksimalno jedanaest godina. Kako Hrvati tako i Srbi iz Banovine živjeli su u prognanstvu odnosno izbjeglištvu, u prosjeku po 5 godina (5,5 - Hrvati i 5,1 - Srbi). Hrvati iz Banovine razdoblje prognanstva proveli su većim djelom u obližnjim naseljima - Sisku, Petrinji, Mraclinu i Odri, dok putanja raseljenih Srba iz Banovine pokazuje njihova lutanja po različitim gradovima i selima Peripanonske Srbije, Istočne Srbije, Jugozapadne Srbije i Vojvodine (Beograd, Požarevac, Smederevo, Zminjak, Topola, Lozovik, Zaječar, Dobrić, Kraljevo, Čestereg, Čurug, Ruma, Grabovci,

Tab. 2. Odnos rođenih u regiji i rođenih drugdje

Tab. 2 The proportion of respondents born in the region and born elsewhere

\begin{tabular}{|l|c|c|c|c|c|c|}
\hline & \multicolumn{2}{|c|}{ Hrvati } & \multicolumn{2}{c|}{ Srbi } & \multicolumn{2}{c|}{ Svega } \\
\hline Rođeni & Broj & $\%$ & Broj & $\%$ & Broj & $\%$ \\
\hline - u regiji & 10 & 47,6 & 26 & 96,3 & 36 & 75,6 \\
\hline - drugdje u Hrvatskoj & 3 & 14,3 & 0 & 0 & 3 & 6,3 \\
\hline - u Srbiji (Vojvodina) & 1 & 4,8 & 0 & 0 & 1 & 2,1 \\
\hline - u BiH & 7 & 33,5 & 1 & 3,7 & 8 & 16,8 \\
\hline Svega & 21 & 100 & 27 & 100 & 48 & 100 \\
\hline
\end{tabular}


Stapar). Prognanički put Hrvata iz BiH prije doseljenja u Banovinu prolazio je, sudeći po anketi, preko Zagreba, Splita, Zadra, slavonskog dijela Hrvatske (Slavonski Brod, Požega, Okučani) te Njemačke. Iako imovinski status nije bio u fokusu istraživanja, ipak pitanje o posjedovanju auta u obitelji (to je pitanje je bilo uključeno u anketu sa svrhom da se procijeni prostorna pokretljivost), može dati barem neku naznaku za usporedbu u tome pogledu. Prema odgovorima na to pitanje, auto u obitelji ima $80 \%$ Hrvata rođenih u Banovini, 46\% Srba rođenih u Banovini i 43\% Hrvata rođenih u BiH.

Iako je vrlo malo sela prije rata imalo etnički potpuno istorodnu populaciju, stanovnici ovoga kraja dijelili su sela prema većinskom stanovništvu na "hrvatska" i "srpska". Izbjeglice Hrvati iz BiH i Vojvodine utječu na promjenu te slike, jer se - kako vidimo iz ankete - dio doseljenih obitelji nastanio u selima s prijeratnim većinskim srpskim stanovništvom (u Jabukovcu, Banskom Grabovcu, Donjoj Bačugi i Moštanici). U cjelini, ipak, etnička diferenciranost sela u velikoj je mjeri ostala obilježje ovoga kraja.

\section{SELEKTIVNOST KOGNITIVNIH KARATA}

Među najčešće korištenim načinima istraživanja kognitivnih karata jesu oni koji od ispitanika zahtijevaju obavljanje određenih grafičkih zadataka. Kartama-skicama, koje se na taj način dobivaju, istraživači se koriste za interpretaciju (ne)podudarnosti prostornih odnosa na kognitivnim kartama s realnim prostornim odnosima. U našem istraživanju ta je tehnika primijenjena na dva načina.

U prvom zadatku ispitanici su zamoljeni da na potpuno čistom listu papira označe svoje selo, a zatim susjedna sela i druga mjesta svojega kraja. Sve na taj način dobivene karte-skice ispitanika bile su, naravno, selektivne, nepotpune. Upravo je ta selektivnost i nepotpunost omogućila provjeru mogućeg utjecaja pojedinih faktora na stvaranje kognitivnih karata. Na kartama ispitanika figurirala su ukupno 33 naselja. Analizom ukupno 236 točaka koje na kartama 48 ispitanika označuju ta naselja izračunana je frekventnost pojavljivanja pojedinih naselja na kartama-skicama ispitanika, koja je dalje križana s različitim mogućim faktorima utjecaja.

Polazilo se od nekoliko pretpostavki. Kao prvo, pretpostavljalo se da komunikacija ima jednu od važnih uloga u formiranju mentalnih predodžbi. Stoga su mjesta koja poznajemo iskustveno, a ne samo posredovano, znatno vitalnija u našim mentalnim prostornim slikama. Pokazalo se da je ta pretpostavka točna. Korelacija među brojem ispitanika koji su posjetili određeno naselje s brojem ispitanika koje su isto naselje unijeli u svoju kartu vlastitoga kraja pokazala se vrlo visokom $(0,7465)$.

Druga je pretpostavka bila sljedeća. Kao što je poznato iz mnoštva geografskih radova (konačno, na tome je zasnovan i geografima dobro poznat gravitacijski model), interakcija odnosno komunikacija među naseljima proporcionalna je broju stanovnika tih naselja. Kao što smo vidjeli gore, komunikacija je važan faktor u formiranju selektivne prostorne predodžbe. Prema tome, na kartama-skicama trebala bi postojati tendencija ucrtavanja većih naselja i izostavljanja malih. U našem istraživanju to se nije pokazalo točnim. Naime, nije pronađena veza između broja stanovnika naselja (ni iz 1991., ni iz 2001., ni s početka 
Laura Šakaja - Kognitivne karte i post-konfliktno stanje:

slika vlastitoga kraja učenika osnovne škole Jabukovac (Banovina)

$2004^{3}$ ) i frekventnosti pojavljivanja toga naselja na kognitivnim kartama (korelacija s brojem stanovnika iz 1991. je 0,2413, iz 2001. - 0,0961, a iz 2004. - 0,1780). Štoviše, naš je uzorak još jednom pokazao da gravitacijsko pravilo, prema kojemu bi broj posjeta trebao biti proporcionalan veličini naselja, nije univerzalno. Naime, u ovome istraživanju nije pronađena veza između broja stanovnika naselja i broja ispitanika koji su to naselje posjetili (korelacija je 0,1490). Očito je da u ruralnim područjima, gdje naselja uglavnom ne obavljaju uslužne djelatnosti i među selima nema značajne međusobne funkcionalne povezanosti, aktualna komunikacija ne ovisi o broju stanovnika pojedinoga naselja, kao što je to slučaj s gradovima. Dakle, vjerojatnost da će selo biti izrazitije zastupljeno na kognitivnoj karti nije toliko povezana s brojnošću njegovih stanovnika koliko s osobnim iskustvima (npr., žive li tamo prijatelji, rodbina, simpatije).

Prema Golledgeu emotivni odnosi i kultura mogu imati vrlo važan utjecaj na kognitivne prostorne predodžbe (Golledge prema Kitchin i Blades, 2002, 43, 54). Portugali i Haken (1992.) pokazali su da se kognitivne karte pripadnika različitih kultura koji žive u istom području razlikuju. Istraživani su Židovi i Arapi, a pokazalo se da na kognitivnim kartama i jednih i drugih postoji tendencija izostavljanja područja na kojima žive pripadnici druge etničke skupine. Dakle, kako zaključuju Portugali i Haken, nacionalizam, odnosno kulturalizam, jedan je od filtara preko kojih ljudi izgrađuju svoje kognitivne karte. Naša je pretpostavka bila da bi se na kognitivnim kartama djece koja naseljavaju području multietničke i post-konfliktne Banovine mogla pojaviti ista etnički obojena selektivnost. Međutim, ta se pretpostavka nije opravdala. Koeficijent korelacije među udjelom učenika određene narodnosti u ukupnoj masi učenika koji su određena sela ucrtali u svoju kartu-skicu, i udjelom te narodnosti u odgovarajućim naseljima dosta je $\operatorname{nizak}^{4}(0,3578 \text { za Hrvate } 0,3742 \text { za Srbe })^{5}$.

Još je od utjecajnog Lynchevoga istraživanja poznato da u formiranju mentalnih predodžbi o prostoru vrlo važnu ulogu imaju putanje kojima se ljudi kreću (Lynch, 1960.). Prema Siegelu i Whiteu (1975.), u procesu mentalnoga osvajanja prostora upoznavanje ruta prethodi upoznavanju konfiguracije prostora ( $\mathrm{tj}$. mnoštva prostornih odnosa među mnoštvom lokacija) (Siegel i White prema: Uttal i Tan, 2000, 150). Naše je istraživanje pokazalo da su rute po kojima se kreće doista okosnica mentalne slike prostora naših ispitanika. Naime, crtajući svoje karte-skice, ispitanici su u prvome redu na njima označivali naselja kroz koja oni svakodnevno prolaze na putu do škole. Korelacija udjela djece koja su ucrtala određena naselja u svoje mentalne karte i udjela djece koje ta naselja prolaze na putu prema školi izrazito je visoka $(0,8148)$.

\section{DISTORZIJE UDALJENOSTI I SMJERA}

Tehnika analize karata-skica u našem je istraživanju bila primijenjena i u svrhu procjene i interpretacije iskrivljenja prostornih odnosa: udaljenosti i smjerova. Pred ispitanike je ponovno bio postavljen zadatak sličan prvome. Razlika je bila samo u tome da su ispitanici trebali na karti-skici 2 označiti vlastito selo te susjedna i druga sela svojega kraja, ali ne na potpuno čistom listu papira (kao na karti-skici 1.), nego na papiru s trima lociranim referentnim točkama. Na drugome je papiru, naime, već bio ucrtan Jabukovac, gdje se nalazi njihova škola, te dva najbliža grada - Petrinja i Glina. Tako su njihove skice bile 
usmjerene prostornim indicijama (spatial cued responce). Fiksne referentne točke odredile su fiksni omjer karata-skica ispitanika i tako omogućile usporedbu udaljenosti i smjerova (pravaca), te analizu njihova nepodudaranja s realnim udaljenostima i smjerovima.

Iako su u drugom zadatku ispitanici na kartu-skicu 2 većinom ucrtali ista naselja koja su ucrtali i na kartu-skicu 1, broj ucrtanih naselja bio je manji (206), jer se Jabukovac već nalazio na karti kao referentna točka. Karte-skice ispitanika bile su skenirane i uz pomoć referentnih točaka preklopljene s aktualnom digitalnom kartom Hrvatske. Za svako su naselje na karti-skici svakoga ispitanika zatim pronađene kognitivne (procijenjene) koordinate, a iz njih i procijenjene udaljenosti među selom u kojem ispitanik živi i drugim naseljima koje je ispitanik ucrtao u svoju kartu-skicu:

$$
\begin{aligned}
& \mathrm{Ak}=\sqrt{(\mathrm{Xn}-\mathrm{Xo})^{2}+(\mathrm{Yn}-\mathrm{Yo})^{2}} \\
& \text { gdje je }
\end{aligned}
$$

Ak procijenjena udaljenost među parom naselja na kognitivnoj karti,

Xo i Yo su koordinate vlastitoga naselja na kognitivnoj karti,

$\mathrm{Xn}$ i Yn - koordinate drugih naselja prikazanih na kognitivnoj karti.

Po istoj su formuli iz stvarnih koordinata računane stvarne udaljenosti. Zatim je računana distorzija udaljenosti, tj. razlika među kognitivnom (procijenjenom) međusobnom udaljenošću dvaju naselja (vlastitoga i nekog drugog) i stvarnom udaljenošću tih istih dvaju naselja.

\section{Udaljenost}

U mnogim dosadašnjim istraživanjima koja su se bavila analizom distorzija udaljenosti i smjerova, distorzije su određivane usporedbom stvarnih koordinata određene lokacije s prosjekom procijenjenih (kognitivnih) koordinata te lokacije. Takve prosječne procijenjene koordinate dobivane su agregacijom procijenjenih koordinata jedne te iste lokacije na kognitivnim kartama svih ispitanika. U posljednje vrijeme sve se više odustaje od takve vrste agregacije i smatra se da ona "uglavnom maskira pravo kognitivno prostorno znanje pojedinaca" (Kitchin i Fotheringham, 1997, 271), odnosno da "uprosječivanje koordinatnih podataka različitih subjekata u svrhu određivanja osobina tipične individualne kognitivne karte može ne odražavati točnost ili karakter distorzija na takvim kartama”, (Lloyd, 1989, 123) te "dovesti do kompletno pogrešnih zaključaka" (Lloyd, 1989, 111). U našem slučaju, gdje su karte-skice bile crtane iz različitih prostornih perspektiva (budući da ispitanici žive u različitim selima), takvo bi uprosječivanje gubilo svaki smisao. Upravo su stoga u ovoj analizi procijenjene koordinate naselja i udaljenosti na karti-skici svakoga ispitanika individualno uspoređivane sa stvarnim koordinatama i udaljenostima odgovarajućih naselja, a tako dobivene distorzije udaljenosti zatim su grupirane.

Općenito uspoređujući kognitivne i stvarne lokacije, možemo primijetiti fenomen zapažen i u drugim istraživanjima (Lloyd, 1989): na kognitivnim kartama izražena je tendencija precjenjivanja udaljenosti (u našem uzorku u 69,9\% svih prikazanih naselja udaljenosti su bili precijenjene). Na pozadini takve opće tendencije zapažamo i drugo poznato pravilo (Lloyd, 1989): distance bliskih mjesta precjenjuju se, dok se distance dalekih mjesta-podcjenjuju. Slika 2 pokazuje da karakter distorzije (podcjenjivanje ili precjenjivanje) u velikoj mjeri ovisi o stvarnoj udaljenosti naselja. U našem se uzorku kratke stvarne udaljenosti - do otprilike $5 \mathrm{~km}$ - na kognitivnim kartama u većini slučajeva precjenjuju (tj. procjenju- 


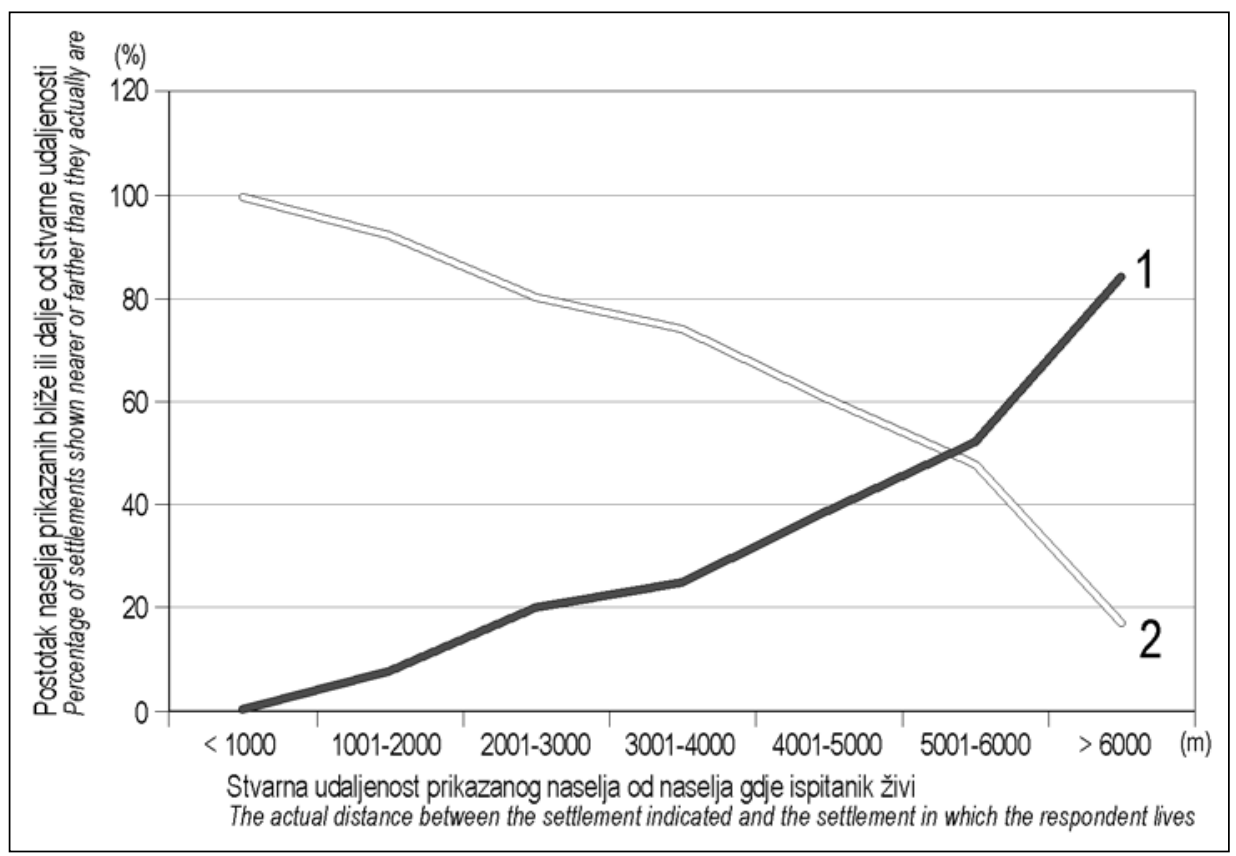

S1. 2. Distorzije u procjeni udaljenosti na kognitivnim kartama i stvarna udaljenost naselja

Fig. 2 Distortions in estimating distances on cognitive maps and real distances between settlements

ju se kao dulje), dok se stvarne distance dulje od $5 \mathrm{~km}$ u većini slučajeva podcjenjuju (tj. procjenjuju se kao kraće). Ovaj je nalaz posve u skladu s fenomenom koji se u literaturi naziva distorzijom po tipu povećala. To znači da su "područja koja se nalaze blizu uporišta dobro poznata, te će kognitivna karta, prilagođavajući se detaljnijem znanju tih područja, na tim mjestima biti 'rastegnuta"” (v. Kitchin i Blades, 2002, 39).

Gore smo već isticali da je komunikacija važan faktor formiranja strukture kognitivnih karata. Kao što smo vidjeli, ispitanici su u svoje karte-skice češće ucrtavali naselja koja su posjetili. No na koje se lokacije ta naselja ucrtavaju? Na prvi bi se pogled moglo činiti logičnim da će nam se nakon posjeta nekome mjestu ono činiti prostorno bližim te ćemo ga na kognitivnoj karti smjestiti na manjoj udaljenosti od stvarne? Kako vidimo iz Tablice 3 u našem uzorku - ovisnost je upravo suprotna, tj. procijenjena udaljenost do naselja koja su ispitanici posjetili najčešce je veća nego što je stvarna udaljenost (statistička značajnost $\mathrm{p}<0,01)$. Tu ovisnost možemo vjerojatno neposredno povezati s gore spomenutim efektom povećala. Naselja koja se posjećuju - to su u prvome redu najbliža i dobro poznata susjedna naselja, te se - u skladu s efektom povećala - razmaci među njima i selima u kojima ispitanici žive povećavaju na kognitivnim kartama.

Dobre ceste svakako su čimbenik koji smanjuje napor savladavanja puta i vrijeme potrebno za put. Stoga smo pretpostavili da bi činjenica dobre cestovne povezanosti naselja mogla utjecati na pozicioniranje tih naselja na kognitivnim kartama. Pokazalo se da unutar našega uzorka doista postoji tendencija podcjenjivanja udaljenosti onih naselja koja se nalaze na državnim ili županijskim cestama (statistička značajnost p < 0,05) (v. Tab. 3). 
Tab. 3. Faktori distorzije udaljenosti i njihova statistička značajnost

Tab. 3 Factors in the distortion of distance and their statistical significance

\begin{tabular}{|c|c|c|c|}
\hline $\begin{array}{l}\text { Naselja na kognitivnim } \\
\text { kartama }\end{array}$ & $\begin{array}{l}\text { Naselja prikazana dalje } \\
\text { nego što jesu }\end{array}$ & $\begin{array}{l}\text { Naselja prikazana bliže } \\
\text { nego što jesu }\end{array}$ & Ukupno \\
\hline \multicolumn{4}{|c|}{ Faktor komunikacije } \\
\hline $\begin{array}{l}\text { Naselja u kojima su učenici } \\
\text { bili }\end{array}$ & \begin{tabular}{|l|}
106 \\
$77,4 \%$ \\
$73,6 \%$ \\
\end{tabular} & $\begin{array}{l}31 \\
22,6 \% \\
50,0 \% \\
\end{array}$ & \begin{tabular}{|l|}
137 \\
$100 \%$ \\
$66,5 \%$ \\
\end{tabular} \\
\hline $\begin{array}{l}\text { Naselja u kojima učenici nisu } \\
\text { bili }\end{array}$ & \begin{tabular}{|l}
32 \\
$64,0 \%$ \\
$22,2 \%$ \\
\end{tabular} & $\begin{array}{l}18 \\
36,0 \% \\
29,0 \% \\
\end{array}$ & \begin{tabular}{|l|}
50 \\
$100 \%$ \\
$24,3 \%$ \\
\end{tabular} \\
\hline $\begin{array}{l}\text { Prikazana naselja za koje je } \\
\text { nepoznato jesu li učenici u } \\
\text { njima bili ili nisu }\end{array}$ & \begin{tabular}{|l|}
6 \\
$31,6 \%$ \\
$4,2 \%$
\end{tabular} & \begin{tabular}{|l|}
13 \\
$68,4 \%$ \\
$21,0 \%$
\end{tabular} & $\begin{array}{l}19 \\
100 \% \\
9,2 \%\end{array}$ \\
\hline Ukupno & $\begin{array}{l}144 \\
69,9 \% \\
100 \%\end{array}$ & $\begin{array}{l}62 \\
30,1 \% \\
100 \% \\
\end{array}$ & \begin{tabular}{|l|}
206 \\
$100 \%$ \\
$100 \%$ \\
\end{tabular} \\
\hline \multicolumn{4}{|c|}{$\chi^{2}=17,725 d f=2$ značajnost $=0,001$} \\
\hline \multicolumn{4}{|c|}{ Faktor dostupnosti } \\
\hline $\begin{array}{l}\text { Naselja kroz koja prolazi } \\
\text { državna ili županijska cesta } \\
\text { ucrtana u kognitivne karte }\end{array}$ & $\begin{array}{l}60 \\
61,2 \% \\
41,7 \%\end{array}$ & \begin{tabular}{|l|}
38 \\
$38,8 \%$ \\
$61,3 \%$ \\
\end{tabular} & $\begin{array}{l}98 \\
100 \% \\
47,6 \%\end{array}$ \\
\hline $\begin{array}{l}\text { Naselja kroz koja ne prolazi } \\
\text { ni državna ni županijska cesta } \\
\text { ucrtana u kognitivne karte }\end{array}$ & \begin{tabular}{|l|}
84 \\
$77,8 \%$ \\
$58,3 \%$
\end{tabular} & $\begin{array}{l}24 \\
22,2 \% \\
38,7 \%\end{array}$ & $\begin{array}{l}108 \\
100 \% \\
52,4 \%\end{array}$ \\
\hline Ukupno & \begin{tabular}{|l|}
144 \\
69,9 \\
$100 \%$ \\
\end{tabular} & $\begin{array}{l}62 \\
30,1 \% \\
100 \% \\
\end{array}$ & $\begin{array}{l}206 \\
100 \% \\
100 \%\end{array}$ \\
\hline \multicolumn{4}{|c|}{$\chi^{2}=6,692 d f=1$ značajnost $=0,010$} \\
\hline \multicolumn{4}{|c|}{ Faktor mobilnosti } \\
\hline $\begin{array}{l}\text { Naselja koja su ucrtali učenici } \\
\text { čija obitelj posjeduje auto }\end{array}$ & \begin{tabular}{|l|}
80 \\
$73,4 \%$ \\
$55,6 \%$
\end{tabular} & $\begin{array}{l}29 \\
26,6 \% \\
46,8 \%\end{array}$ & $\begin{array}{l}109 \\
100 \% \\
52,9 \%\end{array}$ \\
\hline $\begin{array}{l}\text { Naselja koja su ucrtali učenici } \\
\text { čija obitelj ne posjeduje auto }\end{array}$ & \begin{tabular}{|l}
64 \\
$66,0 \%$ \\
$44,4 \%$
\end{tabular} & \begin{tabular}{|l}
33 \\
$34,0 \%$ \\
$53,2 \%$
\end{tabular} & $\begin{array}{l}97 \\
100 \% \\
47,1 \%\end{array}$ \\
\hline Ukupno & \begin{tabular}{|l}
144 \\
$69,9 \%$ \\
$100 \%$
\end{tabular} & \begin{tabular}{|l}
62 \\
$30,1 \%$ \\
$100 \%$
\end{tabular} & $\begin{array}{l}206 \\
100 \% \\
100 \%\end{array}$ \\
\hline
\end{tabular}


Laura Šakaja - Kognitivne karte i post-konfliktno stanje:

slika vlastitoga kraja učenika osnovne škole Jabukovac (Banovina)

\begin{tabular}{|l|l|l|l|}
\hline \multicolumn{4}{|c|}{ Faktor etničke diferencijacije* } \\
\hline "Naša"** sela na kognitivnim & 70 & 26 & 96 \\
kartama & $72,9 \%$ & $27,1 \%$ & $100 \%$ \\
& $66,0 \%$ & $52,0 \%$ & $61,5 \%$ \\
\hline \multirow{2}{*}{ "Njihova"*** sela na } & 33 & 20 & 53 \\
kognitivnim kartama & $62,3 \%$ & $37,7 \%$ & $100 \%$ \\
& $31,1 \%$ & $40,0 \%$ & $34,0 \%$ \\
\hline \multirow{3}{*}{ Ostalo**** } & 3 & 4 & 7 \\
& $42,9 \%$ & $57,1 \%$ & $100 \%$ \\
& $2,8 \%$ & $8,0 \%$ & $4,5 \%$ \\
\hline \multirow{2}{*}{ Ukupno } & 106 & 50 & 156 \\
& $67,9 \%$ & $32,1 \%$ & $100 \%$ \\
\hline$\chi^{2}=3,898 d f=2 \quad 1$ značajnost $=0,142$ & $100 \%$ & $100 \%$ \\
\hline
\end{tabular}

* Značajnost faktora etničke diferencijacije računala se samo za ispitanike rođene u regiji

** Sela u kojima Hrvati čine većinu i koja se pojavljuju na kartama učenika hrvatske narodnosti te sela u kojima Srbi čine većinu i koja se pojavljuju na kartama učenika srpske narodnosti

*** Sela u kojima Srbi čine većinu i koja se pojavljuju na kartama učenika hrvatske narodnosti te sela u kojima Hrvati čine većinu i koja se pojavljuju na kartama učenika srpske narodnosti

**** Zaseoci (prikazani na kartama) za koje nema popisnih podataka o etničkoj strukturi (podaci o narodnosnoj strukturi odgovaraju popisu 1991).

* The significance of the factor of ethnic differentiation was calculated only for respondents born in the region

** Villages in which Croats make up the majority population and which appear on maps drawn by ethnically Croat pupils and villages in which Serbs make up the majority population and which appear on maps drawn by ethnically Serb pupils.

*** Villages in which Serbs make up the majority population and which appear on maps drawn by ethnically Croat pupils and villages in which Croats make up the majority population and which appear on maps drawn by ethnically Serb pupils.

**** Hamlets (drawn on the maps) for which there is no census data in regard to their ethnic structure (i.e. data on ethnic structure, according to the 1991 census).

Posjedovanje auta u obitelji trebalo bi djelovati u istome smjeru. Brown i Broadway (1981.), međutim, u istraživanju čimbenika koji među adolescentskom populacijom utječu na procjenu međugradskih udaljenosti, pokazali su da automobil postaje važan faktor $u$ formiranju kognitivne karte samo kada se koristi aktivno, a ne pasivno, tj. kada ga osoba vozi sama. Iz tablice vidimo doista da mobilnost vezana uz posjedovanje auta u obitelji nije čimbenik koji utječe na dječju procjenu udaljenosti - djeca ne voze, nego su vožena (statistička značajnost $\mathrm{p}>0,05$ ).

Kao što je već spomenuto, dosadašnja istraživanja kognitivnih karata bavila su se $\mathrm{i}$ utjecajem nematerijalnih čimbenika - osjećaja, stavova itd. - na formiranje kognitivnih karata. Pokazalo se da pozitivan stav, u odnosu na lokaciju, smanjuje procijenjene udaljenosti (Briggs, 1973, prema Tverski, 2000, 29). Polazeći od toga - pretpostavili smo da bi na području nedavnoga etničkoga konflikta diferencijacija na sela čiji stanovnici pripadaju vlastitoj etničkoj skupini ("naša sela", tj. većinski srpska za Srbe i većinski hrvatska za Hrvate) i sela čiji stanovnici pripadaju tuđoj etničkoj skupini ("njihova sela", tj. većinski srpska za Hrvate i većinski hrvatska za Srbe) mogla biti izražena i na kognitivnim 
kartama. Međutim, veza među podjelom zajedničkoga prostora na "naša" i "njihova" sela i sustavnim distorzijama udaljenosti nije pronađena ${ }^{6}$. Nije, naime, zabilježeno ni sustavno precjenjivanje ni sustavno podcjenjivanje distance. Faktor podjele na "naše" i "njihovo" izgleda ne utječe na strukturu kognitivnih karata naših ispitanika (statistička značajnost p > 0,05). Djeca post-konfliktne Banovine iz našega uzorka ili (još?) ne dijele sela na "naša" i "njihova", ili je ta podjela irelevantna u procjeni prostornih odnosa.

\section{Smjer}

Distorzija smjerova bila je istražena na osnovi usporedbe procijenjenih i stvarnih azimuta naselja prikazanih na karti-skici pojedinih ispitanika (u odnosu na vlastito naselje ispitanika). Najprije smo pronašli kut $\beta$ među meridijanom na topografskoj karti i smjerom prema naselju prikazanom na karti-skici, gledano iz perspektive ispitanikova sela. Kut $\beta$ nalazimo iz pozitivnog značenja tangensa $\beta$, pritom je

$\operatorname{tg} \beta=(\mathrm{Xn}-\mathrm{Xo}) /(\mathrm{Yn}-\mathrm{Yo})$

gdje su Xo i Yo koordinate sela u kojem ispitanik živi,

$\mathrm{Xn}$ i Yn su koordinate drugih sela $(n)$ u odnosu na koje se računa azimut.

Iz kutova $\beta$ što ih tvore meridijan i smjer prema naselju $n$, računamo azimut $\alpha$ naselja $n$ tako da:

$$
\begin{aligned}
& \alpha=\beta \text { ako je } \mathrm{Xn}-\mathrm{Xo}>0 \text { te } \mathrm{Yn}-\mathrm{Yo}>0 ; \\
& \alpha=180-\beta \text { ako je } \mathrm{Xn}-\mathrm{Xo}>0 \text { te } \mathrm{Yn}-\mathrm{Yo}<0 ; \\
& \alpha=180+\beta \text { ako je } \mathrm{Xn}-\mathrm{Xo}<0 \text { te } \mathrm{Yn}-\mathrm{Yo}<0 ; \\
& \alpha=360-\beta \text { ako je } \mathrm{Xn}-\mathrm{Xo}<0 \text { te } \mathrm{Yn}-\mathrm{Yo}_{0}>0 .
\end{aligned}
$$

Na temelju usporedbe procijenjenih azimuta sa stvarnim azimutima mogu se zapaziti određeni tipovi distorzija smjerova.

1. Zaokruživanje svih smjerova na generalne pravce jedan je od oblika simplifikacije koja, kao što je poznato, općenito karakterizira kognitivne karte. Na Slikama 3a i 3b, 4ai 4b,

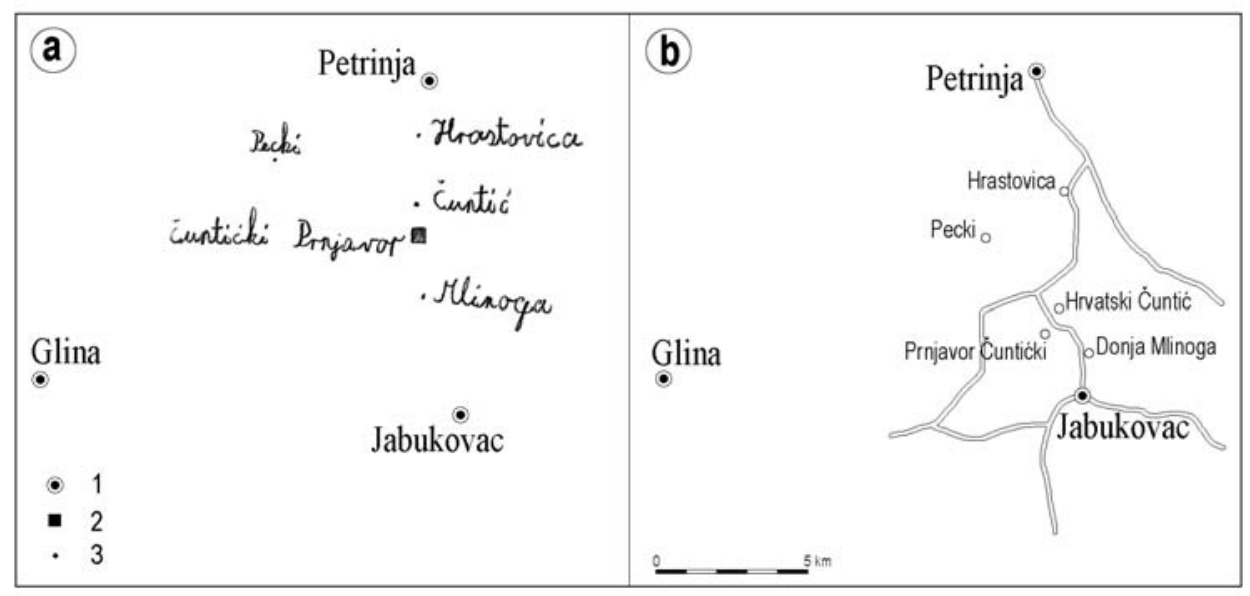

S1. 3. Primjeri distorzija smjerova

Fig. 3 Examples of direction distortions 


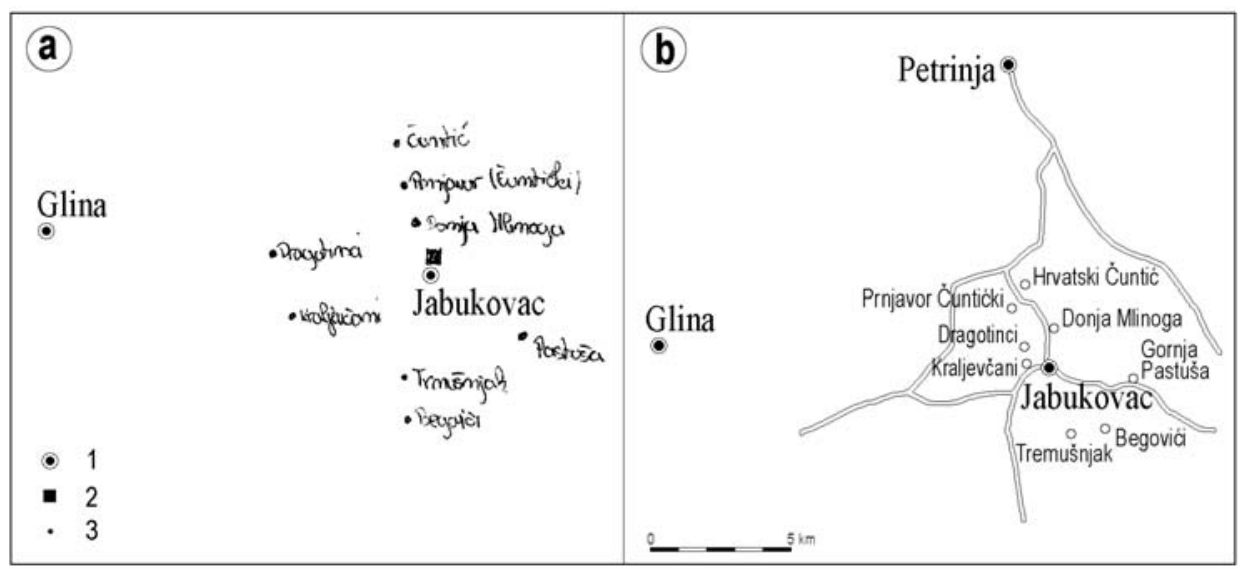

S1. 4. Primjeri distorzija smjerova

Fig. 4 Examples of direction distortions

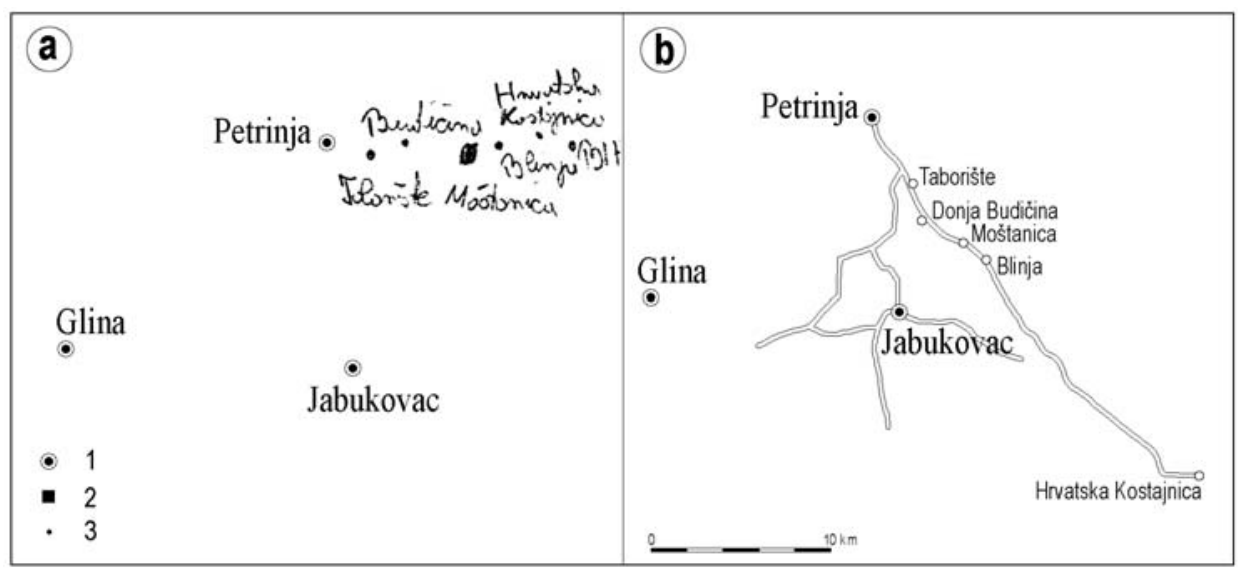

S1. 5. Primjeri distorzija smjerova

Fig. 5 Examples of direction distortions

Legenda (Sl. 3, 4, 5) / Legend (Fig. 3, 4, 5)

a) Karta-skica ispitanika / a) The respondent's sketch-map

1. Referentne točke (Jabukovac, Petrinja, Glina) / Referent points (Jabukovac, Petinja, Glina)

2. Naselje koje je ispitanik/ispitanica označio/označila kao svoje selo/Settlement that the respondent indicated as his or her own village

3. Naselja koja je ispitanik/ispitanica označio/označila kao susjedna sela i druga mjesta njegova/njezina kraja I Settlements that the respondents indicated as neighbouring villages or other places in his or her region b) Usporedna realna karta / b) Comparative actual map

5 a i 5 b dobro vidimo tendenciju zaokruživanja na četiri osnovna smjera: sjever, jug, zapad, istok. Inače karta-skica na Slici $5 a$, koju je nacrtala učenica Hrvatica - izbjeglica iz $\mathrm{BiH}$ (Doboj), vrlo dobro pokazuje da njezina kognitivna karta okolnoga kraja ne samo svodi pravce na pravac zapad - istok, nego se u cjelini orijentira prema $\mathrm{BiH}$, odnosno prema Doboju koji se očito u njezinoj percepciji smješta na istoku (umjesto na jugoistoku) u odnosu na njezino selo. 
2. Drugi tip simplifikacije uočljiv na kartama naših ispitanika jest izravnavanje smjerova. Naselja koja na cesti slijede jedno iza drugoga percipiraju se kao naselja u pravocrtnom nizu, ako cesta naglo ne mijenja svoj smjer (v. npr. naselja Hrastovica, Hrvatski Čuntić, Prnjavor Čuntićki, Donja Mlinoga i Jabukovac na Slici $3 a$ i naselja Prnjavor Čuntićki i Donja Mlinoga na Slici 7a).

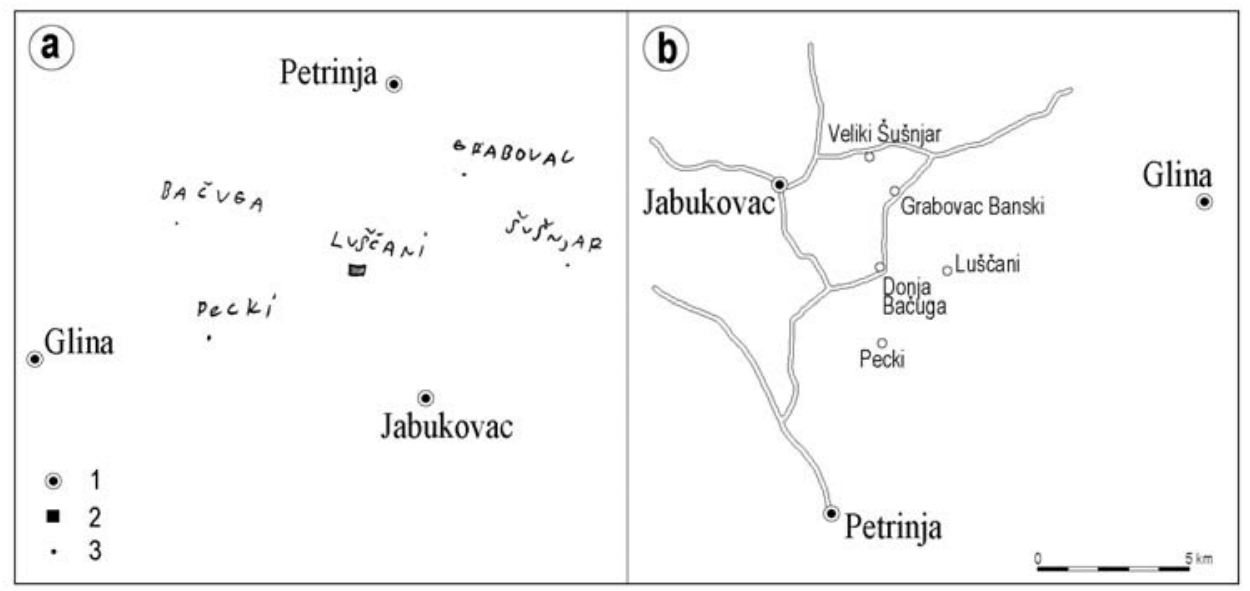

S1. 6. Primjeri distorzija smjerova

Fig. 6 Examples of direction distortions

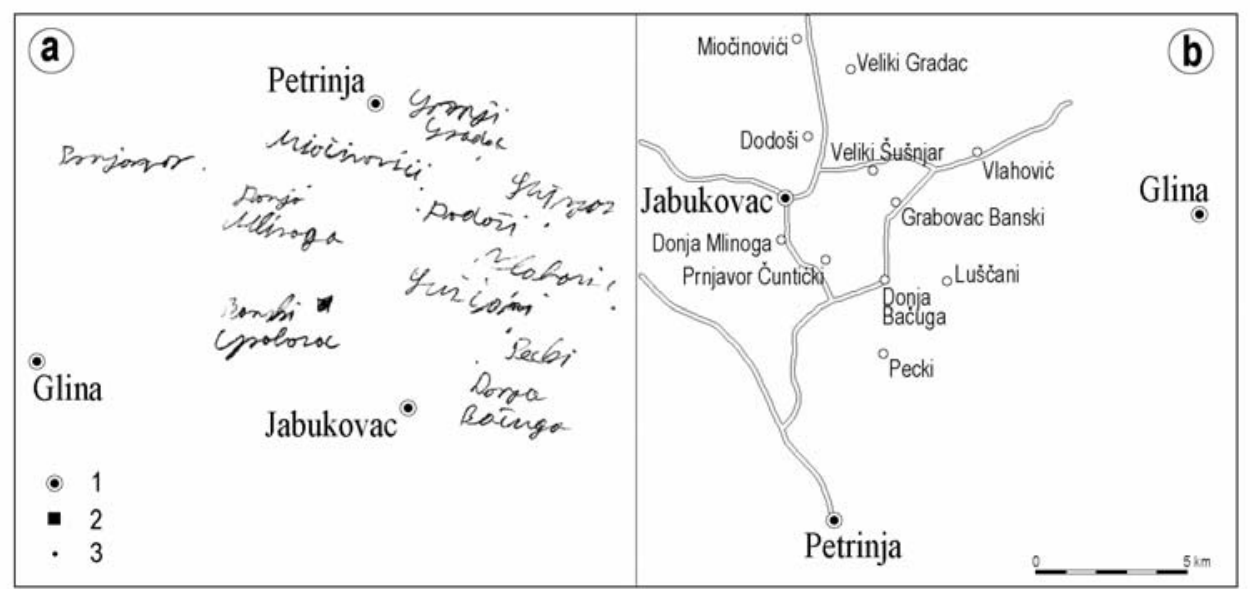

S1. 7. Primjeri distorzija smjerova

Fig. 7 Examples of direction distortions

Legenda (S1. 6, 7) / Legend (Fig. 6, 7)

a) Karta-skica ispitanika / a) The respondent's sketch-map

1. Referentne točke (Jabukovac, Petrinja, Glina) / Referent points (Jabukovac, Petinja, Glina)

2. Naselje koje je ispitanik/ispitanica označio/označila kao svoje selo/Settlement that the respondent indicated as his or her own village

3. Naselja koja je ispitanik/ispitanica označio/označila kao susjedna sela i druga mjesta njegova/njezina kraja I Settlements that the respondents indicated as neighbouring villages or other places in his or her region b) Usporedna realna karta / b) Comparative actual map 
Laura Šakaja - Kognitivne karte i post-konfliktno stanje:

slika vlastitoga kraja učenika osnovne škole Jabukovac (Banovina)

3. Pojedine karte-skice naših ispitanika u cjelini su zarotirane. Pritom se, kada se dogodila takva rotacija, u većini slučajeva u njoj mogla prepoznati orijentacija prema cesti - glavnoj poveznici s drugim naseljima. Na Slikama $6 a$ i $6 b$ te $7 a$ i $7 b$ dobro vidimo da su, bez obzira na zadane referentne točke (Petrinju, Glinu i Jabukovac), karte-skice okrenute tako se da iznad naselja gdje ispitanici žive (iz perspektive crtača karte - ispred) ne nalazi sjever, nego je perspektiva okrenuta (zarotirana) u skladu s glavnim pravcem jutarnjeg puta u školu. Upravo zbog svakodnevnog putovanja očito i cesta, uz vlastito naselje, ponekad postaje motrištem s kojega se sagledava okolni prostor. Rotacije takve vrste pokazuju da okosnice oko kojih se slažu mentalne prostorne predodžbe često nisu apsolutni pravci (sjever, jug, zapad, istok), nego relativni pravci - sprijeda (naprijed), straga (nazad), slijeva (lijevo), zdesna (desno).

\section{Dob, spol i točnost procjene udaljenosti i smjera}

O temi dobno-spolnih razlika u kognitivnom kartiranju postoji golema literatura. Naš je uzorak od 48 ispitanika, naravno, premalen da bi se iz njega izvodili zaključci o spolnim i dobnim razlikama u odstupanjima pri prikazivanju okoline na kartama-skicama. Za takve zaključke potreban je i veći uzorak i koncepcija istraživanja posebno usmjerena na evidentiranje dobno-spolnih razlika. Ipak, bez pretenzije na uopćavanje, u našem uzorku možemo zapaziti da se veličina odstupanja u procjeni prostornih odnosa, prvenstveno smjerova, s uzrastom smanjuje, dok se, s druge strane, ovisnost veličine distorzije o spolu ne vidi.

\section{NEFORMALNO GEOGRAFSKO ZNANJE}

Pitanju gdje uvijek prethodi pitanje što. Naselja nisu točke na karti-skici. Svako od njih ima svoje stanovnike, morfologiju, pejzaž, sa svakim su vezani društveni stereotipi i osobne asocijacije. Za istraživanje svakodnevnoga geografskoga znanja ispitanika samo karte-skice nisu dovoljne. Stoga su uz crtanje karata-skica učenici bili zamoljeni da odgovore na niz pitanja o kraju, selu, susjednim selima.

Neformalno geografsko znanje naših ispitanika, kako pokazuju njihovi odgovori, strukturirano je poput kakva klasična udžbeničkoga geografskog pregleda. U njemu je sav spektar geografskih obilježja, od prirodnih do društvenih. Analizirajući kako ispitanici opisuju selo koje najbolje poznaju, tj. vlastito selo i vlastiti kraj, otkrivamo ustvari specifično geografsko područje očima njegovih mladih stanovnika. Kada opisuju svoj kraj i njegova pojedina sela, učenici su zapravo u ulozi geografa: moraju reći što je u određenom području specifično i prepoznatljivo.

Počnimo od opisa susjednih sela dobivenih iz odgovora na niz pitanja o njima. Suhi geografski jezik - reljef, hidrografija, vegetacija, fauna, pejzažne cjeline - preveden na dječji jezik izgleda ovako: "selo stoji na brdu”, "jako brdovito", "mnogo brežuljaka", "puno brdovitih pašnjaka", "ima čist zrak, pitku vodu", "ima mnogo šuma i livada", "lijepe šume - veliko drveće", "ogromne livade", "ima jedna pećina", "ima dva potoka", "velika rijeka", "divlje životinje - svinje, fazani, jeleni i druge", "nehotice se vidi kako preko ceste pretrče divlje svinje, zečevi, nekad možda i lisica". 
Vrlo se često u opisivanju kraja spominju ekološki problemi: nekontrolirana sječa te osobito zagađenost. U odgovorima se vrlo često pojavljuju riječi "smeće" i "otpad": "smeće - ima ga svuda", "divlja odlagališta otpada", "rijeka u kojoj znam sa bratom skupljati smeće", "smeće oko rijeka", "potoci su onečišćeni", "nekontrolirana smetlišta", "smeće oko Petrinjčice" i sl. Čini se da ekološkoj svijesti znatno pridonosi činjenica da zagađenost prerasta iz apstraktnog u vrlo konkretan problem: naime, onečišćenost rijeka i potoka sasvim konkretno ugrožava jednu od malobrojnih raspoloživih zabava - kupanje.

Susjedna naselja za djecu su prepoznatljiva po njihovoj veličini ("veliko selo”, "malo selo", "dugo preko 6,5 km" i sl.), strukturi ("ima više dijelova", "postoji gornji i donji Grabovac", "ima puno zaselaka") i morfologiji ("puno kuća", "neke kuće drvene", "puno napuštenih kuća", "razrušene kuće", "kuće koje nisu naseljene", "obnovljene naseljene kuće", "nisu sve ceste asfaltirane", i sl.).

Važan faktor prepoznatljivosti susjednih naselja jest i njihova funkcionalna infrastruktura. Dva njezina djeci najvažnija elementa jesu, sudeći po odgovorima, škola (Jabukovac) i trgovine (nalaze se u ponekim selima). Crkva je, kako se čini, u kognitivne karte također ucrtana kao funkcionalni, a ne pejzažni element prostora, što se vidi iz činjenice da katoličke crkve i kapelice spominju Hrvati, a djeca srpske narodnosti - baptističke crkve, koje su posljednjih godina u Banovini sve utjecajnije.

Funkcija zabave svodi se samo na par objekata na cijelom području istraživanja: igralište u Donjoj Bačugi, stadion u Grabovcu i "prostorija u koju odlazim igrati igrice na kompjuteru” (također u Grabovcu). Društveni dom u Gornjoj Bačugi, obnovljen 2000. godine od strane njemačke nevladine organizacije ASB (Arbeiter Samaritaner Bund) u suradnji s Europskom komisijom, nije nikada profunkcionirao i očito nije zanimljiv čak ni kao orijentir jer u tekstovima nije spomenut ni jednom. Dječji istraživački centar "Petrinjčica" - radionica izvanškolske aktivnosti, lociran u zgradi bivše škole (također obnovljene uz pomoć ASB-a) u Prnjavoru Čuntićkom, iako uspješno ostvaruje svoje ekološke programe (što se može vrlo jasno prepoznati u visokoj ekološkoj osviještenosti djece), ipak za djecu ovoga prostora znači objekt namijenjen prvenstveno nekome drugom - to je "škola za djecu iz drugih škola" zbog koje u njihov kraj “mnogo ljudi dolazi u posjet”. Bez obzira na znatne investicije, nijedan od ta dva obnovljena objekta nije, sudeći po našem istraživanju, bitno pridonio kvaliteti života lokalne mladeži.

Funkciju prostornih markera vrše i spomenici, za koje se međutim čini da se pamte vrlo neodređeno: npr. kao "spomenik veliki”, "veliki spomenik mrtvih", "spomenik ispred stare škole”, i sl. Većina spomenika povezana je s partizanskom prošlošću toga kraja. Stoga su za novu generaciju oni odjeci nekih davnih vremena. Za djecu rođenu u Banovini to su "spomenici po selima, ponos ljudi moga kraja, osobito starijih", a za djecu-doseljenike - neki "kip s crvenom zvijezdom”.

U sklopu neformalnoga geografskoga znanja naših ispitanika društveni je element vrlo bitan. On je sastavljen od demografskih skica ("puno ljudi”, "malo ljudi”, "najviše starih ljudi", "malo djece", "ima različite vrste nacionalnosti”, "ima puno naseljenih iz Bosne", "ljudi se bave poljoprivredom"; zanimljivo je pritom da je imenovanje glavnog etničkoga korpusa naselja obavijeno potpunom šutnjom - etnička se imena u tekstovima ispitanika nijednom ne spominju) i uobičajenih susjedskih stereotipa (u jednom selu su 
Laura Šakaja - Kognitivne karte i post-konfliktno stanje:

slika vlastitoga kraja učenika osnovne škole Jabukovac (Banovina)

"ljudi vrijedni, spremni pomoći”, u dugom - "ljudi nisu složni”, pomalo /su/ bezobrazni i zavidni", u trećem - "stanovništvo stvari voli raditi po starim običajima"). Za mnoge je prepoznatljivost susjednog naselja povezana sa sasvim osobnim razlozima, što još jednom dokazuje teze suvremene humanističke geografije o važnosti emotivnih odnosa pri konstrukciji mjesta: kao što se vidi iz tekstova, razlog za pažnju prema pojedinom mjestu može biti činjenica da tamo živi najbolji prijatelj ili prijateljica, "dečko koji mi se sviđa", "osoba koju volim", "moja rodbina” ili "moji svi prijatelji”.

Privreda, izgleda, manje uzbuđuje dječju imaginaciju. Ipak, pojavljuju se i opisi tipa: "puno neobrađene zemlje", "uz cestu se vidi kako pasu domaće životinje: krave, ovce, koze i poneki konj", ili: selo "ima 10 traktora i 4 kamiona mala".

Svi su opisi, naravno, subjektivni. Jedno te isto - vlastito - selo dva različita trinaestogodišnja dječaka opisuju (percipiraju) na potpuno različit način: jedan o Banskom Grabovcu piše - "ima jedan mali potok, šuma, brda, doline", a drugi - "puno kuća i ljudi, kuće od drveta i od betona, trgovina dolazi kamionom, traktori rade, auti prolaze, velike kuće". Za četrnaestogodišnju djevojčicu isti Banski Grabovac znači: "ljuljačke, ambulanta, nogometno igralište, škola, ali nije obnovljena".

Ipak, svi opisi zajedno daju dosta relevantnu generalnu sliku života ovoga kraja. Njegova današnja specifičnost najviše se, vjerojatno, odražava u dva elementa koja se kao crvena nit provlače kroz odgovore gotovo svakog ispitanika. Prvi element je - naglašenost aspekta (ne)naseljenosti. Je li neko mjesto naseljeno, slabo naseljeno ili gotovo nenaseljeno, ima li u njemu vršnjaka - ključni je element gotovo svakog opisa, jer za djecu ovoga depopulacijskoga dijela Hrvatske s vrlo nepovoljnom dobnom strukturom - društvo vršnjaka izrazito je deficitarno. O svome selu djeca pišu rečenice poput ovih: "volio bi da ima malo više ljudi jer nas je malo, to bi barem volio", "ima više životinja nego ljudi”, "moje je selo ružno, u mom selu nema ljudi". Zamoljeni u anketi da završe rečenicu "U mome kraju ima premalo...", 75 \% ispitane djece tu je rečenicu završilo s "ljudi” ili “djece".

Drugi element današnje situacije ovoga dijela Hrvatske jest aktualnost prošlosti, što je vrlo neuobičajeno za dječju dob. Nekada je "ovdje bila stara škola" (Šušnjar, Banski Grabovac, Jabukovac), "bila je gostionica” (Donja Bačuga), "bio je dobrovoljni vatrogasni dom" (Luščani), nekada je ovo "bilo najljepše selo" (Donja Mlinoga). Intonacija je posve usklađena s ozračjem napuštenih kuća, praznih dvorišta, bezljudnih cesta.

\section{VREDNOVANJE KRAJA}

Ipak, mučan put izbjeglištva očito je naučio cijeniti vlastiti dom. U tekstovima nekih povratnika nalazimo rečenice poput ovih: "za mene je moj kraj moj dom", "moj kraj je život koji me okružuje, njegova ljepota”. S druge strane, negativne rečenice poput već spomenute - “moje je selo ružno..." - mogu se naći uglavnom u tekstovima doseljene djece, a i na pitanje bi li voljeli živjeti negdje drugdje pozitivno je odgovorila točno polovica djece-doseljenika i samo $27 \%$ djece rođene u regiji. Zamoljeni da procijene (od 1 do 5) svoj kraj s različitih aspekata, ispitanici su u cjelini dosta visoko vrednovali vlastito okruženje. Kako pokazuje tablica, najviše vrednovani aspekti kraja jesu ljepota prirode i ugodnost za život, a najniže se vrednuje stupanj bogatstva (v. Tab. 4). Zanimljivo je da doseljenici u prosjeku 
kraj u kojem trenutno žive smatraju manje sigurnim, dosadnijim, turobnijim, a odnose među ljudima manje prijateljskima nego što to misle tamo rođena djeca. Djeca srpske narodnosti sigurnost svoga kraja procjenjuju više od druge djece (vjerojatno zbog toga što je uvjerenje u vlastitu sigurnost jedan od važnih subjektivnih uvjeta je za povratak raseljenih osoba), ali ga vide i razrušenijim (što ne začuđuje ako uzmemo u obzir manju obnovljenost sela sa srpskom većinom). Djeca hrvatske narodnosti koja su rođena u tome kraju odnose među ljudima vide prijateljskijima, a sam kraj obnovljenijim, veselijim i življim.

Tab. 4. Vrednovanje vlastita kraja po pojedinim aspektima

Tab. 4 Evaluating individual aspects of one's own region

\begin{tabular}{|c|c|c|c|}
\hline \multirow{2}{*}{$\begin{array}{c}\text { Polovi na ponuđenim skalama mogućih } \\
\text { karakteristika kraja }\end{array}$} & \multicolumn{3}{|c|}{ Ocijene ispitanika na skali od 1 do 5} \\
\hline & $\begin{array}{l}\text { Hrvati rodeni } \\
\text { u regiji }\end{array}$ & $\begin{array}{l}\text { Srbi rodeni u } \\
\text { regiji }\end{array}$ & $\begin{array}{l}\text { Doseljenici u } \\
\text { regiju }\end{array}$ \\
\hline $\begin{array}{l}5 \text { - lijepa priroda } \\
1 \text { - ružna priroda }\end{array}$ & 4,4 & 4,2 & 4,5 \\
\hline $\begin{array}{l}5 \text { - ugodan za život } \\
1 \text { - neugodan za život }\end{array}$ & 4,5 & 4,1 & 4,6 \\
\hline $\begin{array}{l}5 \text { - čist } \\
1-\text { prljav }\end{array}$ & 3,6 & 3,6 & 3,5 \\
\hline $\begin{array}{l}5 \text { - siguran } \\
1 \text { - nesiguran }\end{array}$ & 4,2 & 4,5 & 3,5 \\
\hline $\begin{array}{l}5 \text { - prijateljski odnosi među ljudima } \\
1 \text { - neprijateljski odnosi među ljudima }\end{array}$ & 4,3 & 4,0 & 3,1 \\
\hline $\begin{array}{l}5 \text { - bogat } \\
1 \text { - siromašan }\end{array}$ & 3,2 & 3,1 & 3,0 \\
\hline $\begin{array}{l}5 \text { - više novih kuća } \\
1 \text { - više ruševina }\end{array}$ & 4,1 & 3,1 & 3,6 \\
\hline $\begin{array}{l}5-\text { veseo } \\
1 \text { - turoban (tužan) }\end{array}$ & 4,5 & 3,9 & 3,5 \\
\hline $\begin{array}{l}5 \text { - različit } \\
1 \text { - jednoličan }\end{array}$ & 4,1 & 4,0 & 4,3 \\
\hline $\begin{array}{l}5 \text { - suvremen } \\
1 \text { - zaostao }\end{array}$ & 3,8 & 3,2 & 3,1 \\
\hline $\begin{array}{l}5 \text { - obnovljen } \\
1 \text { - razrušen }\end{array}$ & 4,0 & 3,3 & 4,0 \\
\hline $\begin{array}{l}5 \text { - zadovoljavajući } \\
1 \text { - nezadovoljavajući }\end{array}$ & 4,2 & 3,9 & 3,2 \\
\hline $\begin{array}{l}5 \text { - živost } \\
1 \text { - dosada }\end{array}$ & 4,0 & 3,8 & 2,6 \\
\hline $\begin{array}{l}5 \text { - lako savladivi svakodnevni problemi } \\
1 \text { - teško savladivi svakodnevni problemi }\end{array}$ & 3,8 & 3,3 & 3,2 \\
\hline $\begin{array}{l}5 \text { - ovdje se zabavljam dobro } \\
1 \text { - ovdje se ne zabavljam dobro }\end{array}$ & 3,8 & 3,9 & 3,7 \\
\hline $\begin{array}{l}5 \text { - odgovara onome što ja želim } \\
1 \text { - ne odgovara onome što ja želim }\end{array}$ & 3,8 & 3,6 & 3,9 \\
\hline
\end{tabular}


Laura Šakaja - Kognitivne karte i post-konfliktno stanje:

slika vlastitoga kraja učenika osnovne škole Jabukovac (Banovina)

\section{PROSTORI IGRE}

Igra čini jednu od bitnih dimenzija dječjega života. Ali gdje se igraju djeca? Kakva je geografija igre? Analizirajući odgovore ispitanika, možemo izdvojiti četiri tipa prostora igre. U prvi tip ulaze prostor kraj kuće i dvorište u raznim varijantama ("bara ispred kuće", "hlad ispod krova", "iza sijena”, i sl.). Atributi koji se vežu uz ovaj tip prostora igre jesu ugodnost i sigurnost. Zanimljivo je da se u odgovorima sama kuća pojavljuje samo jednom kao prostor igre.

Produžetak prostora kuće jest voćnjak ("voćar"). Komentari poput "tamo je mirno i nitko ne dosađuje", "tamo se osjećam sigurno i sretno", volim se igrati tamo "zato što je moj" pokazuju da je to prostor koji je omiljen jer kombinira u sebi sigurnost zbog blizine kuće i mir zbog odvojenosti od nje.

Treći tip prostora igre jest prostor prirode: travnjak, livada, poljana, brdo, mjesto uz potok, dio šume. "Lijepo" je najčešce korišten epitet kada se govori o tom tipu prostora. Ovdje je "sve sretno, zeleno, radosno" - kako se poetski izrazio jedan naš dvanaestogodišnji ispitanik. "Mirisi”, "trava”, “cvijeće”, "drveće”, “čist zrak", "zelenilo", "dobar pogled", "cvrkut ptica" karakteristike su koje se spominju uz ovaj tip prostora, a "osjećam povezanost s prirodom”, "opuštam se i uživam”, "imam svoj mir" - osnovni su osjećaji koji se uz njega vežu.

Četvrti tip prostora igre jest igralište. Ono ima potpuno drugačiju funkciju. To je prostor okupljanja. Ovdje se "svi skupimo pa igramo", "zezamo se", ovdje se "imam s kim i čim igrati”, "tamo mi dolazi najviše prijateljica”. U depopulacijskoj i u ratu razrušenoj Banovini, međutim, nema puno takvih prostora niti u svakom selu djeca mogu pronaći društvo za igru. $36 \%$ ispitanika navelo je da se igraju sami jer se nemaju s kim igrati u svome selu. Mjesto gdje se mogu naći sa svojim prijateljima za njih je uglavnom jabukovačka škola.

S uzrastom se prostorni krug slobodnog kretanja, a tako i prostor igre, primjetno proširuje: izvan sela povremeno se igra $36 \%$ djece 5. razreda, $43 \%$ djece 6 . razreda, $62 \%$ djece 7. razreda i $75 \%$ djece 8 . razreda. Motivacija igre izvan sela, kako djevojčica tako i dječaka (56\% djevojčica i $48 \%$ dječaka igra se izvan sela), prvenstveno je zadovoljavanje potrebe za komunikacijom. Većina ispitanika (64\%) odlazak izvan sela izravno objašnjava potrebom za društvom. To je odlazak "kod prijatelja", "kod najbolje frendice s kojom nikad nije dosadno"”, odlazak u prostor gdje "ima puno djece" i "više života". Pritom je ta motivacija osviještena: "zato što je dobro igrati s nekim nego s nikim", "da se malo zabavim i riješim samoće", ili neosviještena: "ne znam, nekako mi je ljepše”.

Ponekad je igra izvan sela motivirana atributima prostora u koji se odlazi. Za svaku igru potrebni su i posebni prostorni uvjeti: na primjer, nogometno je igralište, gdje "imaju golovi i sve za nogomet”, izrazit faktor međuseoske dječje komunikacije; veliko polje isto je tako prikladno za nogomet, ali i za igru lovice, rukomet i druge igre - jer "ima puno prostora za igru i malo auta”; “žmurke” je, sudeći po svemu, najprikladnija igra za voćnjak gdje "ima šljiva debelih i tankih", iza kojih se može sakriti; igra Tarzana i Indijanaca igra se na velikom brdu "jer je dobar pogled i ima drveća"; livade oko sela izgleda da su pogodne za "trčanje i igranje istraživača"; za bacanje kamenčića u vodu bira se mjesto pokraj rijeke 
gdje je "najljepše žuborenje vode"; stan najbolje prijateljice koja živi u gradu (Petrinji) nije prikladan za spomenute igre, pa se tamo najčešće igra "ne ljuti se".

Ponekad se ti privlačni “drugi prostori” nalaze izvan sela, ali u većini slučajeva oni su u drugim selima. Analizirajući podatke o tome u kojim se selima djeca igraju, dolazimo do zaključka da toj vrsti druženja na vidjelo izlaze etničke podjele: iako postoje i izuzeci, hrvatska djeca uglavnom posjećuje prijatelje u tzv. "hrvatskim" selima (Prnjavoru Čuntićkom, Peckom, Donjoj Budićini), a srpska - u tzv. "srpskim” (u Donjoj Bačugi, Begovićima, ali najviše u Banskom Grabovcu s njegovim očito popularnim nogometnim igralištem $)^{7}$.

\section{PROSTORI STRAHA I RUŽNIH USPOMENA - NEUSPJELI ISTRAŽIVAČKI POKUŠAJ?}

Koja mjesta čine geografiju straha na post-konfliktnom području? Vežu li djeca koja su prošla strahote rata svoje osobne strahove uz određena mjesta ili, govoreći općenito, čega se boje? U vezi s time ispitanicima su bila postavljena dva bloka pitanja; međutim, ona su uglavnom ostala bez odgovora. Indikativno je da od svih 47 anketnih pitanja većina učenika nije odgovorila upravo na pitanja koja su se odnosila na mjesta straha i mjesta ružnih uspomena.

Prvi blok pitanja glasio je: "Postoji li u tvojem kraju (selu) mjesto koje izbjegavaš ili bi se tamo bojao otići? Ako da, koje je to mjesto? Zašto ga izbjegavaš ili se tamo bojiš otići?". $81 \%$ ispitanika odgovorilo je da takvo mjesto ne postoji. Iz ostalih malobrojnih odgovora vidimo da se univerzalnim mjestima straha - grobljima i dubokoj šumi - u postkonfliktnom području pridružuju i druga, specifična mjesta. Neka od njih vezana su uz moguće zaostale mine zbog kojih se izbjegavaju nepoznata područja. Mine su djelomičan uzrok i drugoj vrsti straha što ga je jedan četrnaestogodišnjak imenovao kao "neodređeni strah zbog zapuštenosti". Poslijeratna zapuštenost, sudeći po odgovorima, poziva na oprez, pa se djeca boje zapuštenih njiva, potoka gdje "ima puno smeća i mogu se zaraziti", zapuštenih mjesta gdje "ima pasa koji su kao poludjeli” ("pasa lutalica za koje se nitko ne brine", "dosta odvezanih pasa koje šetaju i hoće napasti”).

Poseban blok pitanja odnosio se na mjesta uspomena. Dok su o mjestima lijepih uspomena djeca davala iscrpne informacije, na pitanje o mjestu s kojim ih vežu ružne uspomene većina ispitanika ili nije odgovorila ili je odgovorila lakonski: "nikojim" ili "nema takvog mjesta". Samo kod izbjeglica iz BiH to pitanje, izgleda, nije izazvalo nelagodu, pa su na njega oni odgovorili gotovo svi. Njihove ružne uspomene, kao što se moglo i očekivati, najčešće su povezane s Bosnom, ratom i pogibijom bližnjih. S druge strane, u tekstovima ispitanika rođenih u regiji rat je gotovo potpuno izbrisan. Samo je njih $22 \%$ priznalo da uopće ima ikakve ružne uspomene, a i oni te uspomene uglavnom vežu za lokacije gdje je doživljen rastanak s dobrim prijateljima, gubitak psa ljubimca, gdje su osjetili strah pred vukovima. Tek $5 \%$ ispitanika rođenih u regiji povezalo je mjesta ružnih uspomena s ratom.

U “dekonstrukcijskom” postupku interpretacije tekstova upravo izostavljanje, prazna mjesta i bjeline, takozvane sjene, smatraju se rječitijima od samoga teksta. Je li odsutnost 
Laura Šakaja - Kognitivne karte i post-konfliktno stanje:

slika vlastitoga kraja učenika osnovne škole Jabukovac (Banovina)

straha u tekstu izraz pubertetskoga junačenja? Je li to znak opreza ili potiskivanja negativnoga i odlučnosti da se okrenu budućnosti? Psiholozi bi vjerojatno uspjeli objasniti zaštoje strah iz tekstova naših ispitanika koji žive na području gdje su se sasvim nedavno događali nezamislivi zločini gotovo u potpunosti izbrisan. U geografskom se članku objašnjenja takvoga tipa čine neprimjerenima.

\section{ZAKLJUČAK}

Kvantitativni pristupi u proučavanju kognitivnih karata pridonose znanju o transformacijama prostornih odnosa pri oblikovanju mentalnih slika o prostoru. Na temelju primjene jednoga od takvih pristupa, tj. analize rukom crtanih karata-skica, u ovome je članku testiran niz pretpostavki o faktorima transformacije prostornih odnosa u procesu stvaranja prostornih slika. Pokazalo se slijedeće:

1. Neposredno znanje čini lokacije vitalnijima u svijesti:

- kao prvo, selekcija pri prijenosu informacije u kognitivne slike ovisi o individualnim neposrednim iskustvima;

- kao drugo, neposredna iskustva utječu na karte u skladu s takozvanim efektom povećala, što znači da se kognitivne karte - prilagođavajući se boljem znanju određenih područja - na takvim mjestima (područjima) "rastežu".

2. Ceste, putevi, putanje izrazito su važni elementi pri formiranju kognitivnih karata. Oni utječu $i$ na selekciju elemenata ina iskrivljavanje odnosa pri psihološkom procesu stvaranja mentalnih slika:

- na karti-skici prije će se pojaviti naselje koje se nalazi na putanji kojom pojedinac svakodnevno prolazi, nego naselje izvan te putanje;

- udaljenosti među naseljima podcjenjuju se (skraćuju) ako se naselje nalazi na frekventnim cestama;

- lokacije koje se nalaze uz cestu percipiraju se kao naselja u ravnom nizu bez obzira na zakrivljenost ceste (osim ako cesta ne mijenja naglo svoj smjer);

- kognitivne se karte rotiraju s obzirom na vitalnu cestu na kojoj se odvija svakodnevna komunikacija; u nizu slučajeva cijela se kognitivna karta ne koncipira iz perspektive vlastitoga naselja, nego iz perspektive vlastite svakodnevne putanje putovanja (kretanja).

Ovim su istraživanjem potvrđene otprije dobro poznate zakonitosti kognitivnih karata:

- zaokruživanje svih smjerova na generalne smjerove - kao oblik simplifikacije u procesu psihološkoga prijenosa;

- varijacija veličine distorzije s obzirom na udaljenost: precjenjivanje udaljenosti bližih mjesta i podcjenjivanje udaljenosti daljih lokacija.

Polazište danoga istraživanja bilo je uvjerenja da kvantitativni pristupi nisu dovoljni za zaključke o tome kakve su zapravo mentalne reprezentacije izvanjske okoline, jer se takvi pristupi fokusiraju na prostornim odnosima te zapostavljaju druge aspekte okoline. Stoga smo se, da bismo upotpunili znanje o kompleksnom načinu doživljavanja vlastite geografske sredine, koristili i kvalitativnim pristupima u analizi tekstualnih odgovora na otvorena anketna pitanja. Rekonstruirajući iz tih odgovora neformalno geografsko znanje o vlastitom kraju dolazimo i do nekih zaključaka o parametrima preko kojih se on doživljava:

- veličina, struktura i morfologija bitni su parametri oko kojih se okuplja neformalno znanje o nekom naselju; 
- od funkcionalnih elemenata naselja za djecu su najvažniji škola, trgovina, mjesto zabave (igralište, stadion) i crkva;

- među znakove prepoznavanja određenog mjesta idu i spomenici, koji se međutim percipiraju kao pejzažni elementi, tj. bez njihove ideološke "težine";

- ljudi su jedan od najvažnijih parametara preko kojih se doživljava naselje. Neformalno znanje o humanom aspektu lokacije zasniva se na trima parametrima: a) na znanju o općim socijalno-demografskim obilježjima stanovnika, b) na stereotipima o stanovnicima naselja i c) na osobnim odnosima s pojedincima.

Jedno od pitanja koja su se postavljala tijekom istraživanja bilo je: kako mladi stanovnici doživljavaju svoj kraj u post-konfliktno doba.

Iako su istraživanja drugih autora pokazala da etnički kulturalizam može djelovati kao filtar pri prenošenju prostornih odnosa na kognitivne karte, u kvantitativnom dijelu našega istraživanja nije se vidjelo da etnički odnosi na bilo koji način utječu na percepciju čisto prostornih relacija: karte-skice ispitanika bile su indiferentne u odnosu na etničke aspekte. Prisutnost kulturalizma izašla je na vidjelo pri analizi tekstualnih odgovora. Tragove kulturalizma, naime, vidimo u činjenici da se područje igre po svoj prilici ograničava samo na naselja s većinskim stanovništvom iste etničke pripadnosti. Kao posljedicu nedavnog međuetničkog konflikta i rata možemo protumačiti i očito izbjegavanje mladih ispitanika da se očituju o osjetljivim temama etničnosti (ni jednom nisu bile spomenute riječi Srbin, Hrvat, srpsko selo, hrvatsko selo), rata i straha.

Znatno je otvorenije izraženo doživljavanje drugih (izvan-etničkih) aspekata kraja, također povezanih s njegovim post-konfliktnim karakterom. Poslijeratna depopulacija stanovništva ionako depopulacijskoga kraja bitno utječe na kvalitetu života djece ovoga kraja: naime, društvo za igru i prilike za međusobnu dječju komunikaciju općenito postaju rijedak privilegij. Stoga je za ispitanike osamljenost vrlo izražen aspekt u doživljavanju vlastita kraja.

Razrušenost stare infrastrukture, nedostatnost i nefunkcionalnost nove određuje za dječji uzrast neočekivane note nostalgičnosti ("nekada je ovdje bilo...") u doživljavanju svoje okoline; znakovi za prepoznavanje lokaliteta često su objekti koji materijalno ili funkcionalno više ne postoje - stara škola, bivši vatrogasni dom i sl.

Manjkavo funkcioniranje komunalnih službi rezultira zapuštenošću, nastankom nekontroliranih smetlišta, zagađenošću potoka i rijeka, povećavajući tako prostor opreza i straha te smanjujući ionako na nekim područjima ograničen prostor kretanja zbog mogućih zaostalih mina.

Iskustvo rata, prognanstva i izbjeglištva očito je naučilo djecu da cijene vlastiti dom. Stoga je stupanj zadovoljstva vlastitim krajem u ispitanika vrlo visok. Ipak, donekle različite životne okolnosti triju grupa stanovnika Banovine (domaći Hrvati, domaći Srbi i doseljeni Hrvati) uzrokuju i određene razlike u evaluaciji različitih aspekata vlastitoga kraja. Srbi-povratnici vide svoj kraj kao vrlo siguran, ali i dosta razrušen. Najzadovoljniji životom u svome kraju jesu Hrvati-povratnici, koji kraj vide kao prijateljski, obnovljeni i živ, a najnezadovoljniji su Hrvati doseljeni iz BiH i Vojvodine, koji kraj vide kao dosadan, turoban, manje siguran i manje prijateljski.

\section{ZAHVALA}

Srdačno zahvaljujem profesorima i upravi Osnovne škole "Jabukovac" te voditelju područnoga ureda misije OESS-a u Petrinji Jean-Pierreu Golubiću za pomoć u realizaciji istraživanja. Posebno zahvaljujem mojim mladim ispitanicima koji su mi svojim dirljivim rečenicama i ozbiljnim, šaljivim, sjetnim ili tužnim komentarima otvorili vrata vlastita svijeta. 
Laura Šakaja - Kognitivne karte i post-konfliktno stanje:

slika vlastitoga kraja učenika osnovne škole Jabukovac (Banovina)

\section{POZIVNE BILJEŠKE}

1. Baza podataka Ureda za prognanike i izbjeglice, prosinac 2003.

2. Istraživanje je provedeno u veljači 2004. godine.

3. Broj stanovnika pojedinih sela na početku 2004. g. procijenjen na način da je podacima iz popisa 2001. za svako selo pribrojen broj raseljenih osoba koje su se vratile u selo 2002. i 2003. godine te $3 / 4$ broja raseljenih povratnika u 2001. (s obzirom na to da je popis proveden na kraju prvoga tromjesečja - 31. ožujka). Korišteni su podaci Ureda za prognanike i izbjeglice, prosinac 2003.

4. S obzirom na to da u rezultatima popisa 2001. nisu objavljeni podaci o etničkoj strukturi naselja, podatak o većinskom stanovništvu deriviran je iz popisa 1991. Pretpostavljamo da se usprkos nešto promijenjenoj etničkoj strukturi lokalna predodžba o tome koje je selo "srpsko", a koje je "hrvatsko" - nije znatno promijenila.

5. Ništa se ne mijenja i ako isključimo mentalne karte doseljenih učenika (Hrvata iz Bosne i Hercegovine i Vojvodine). Korelacijski koeficijenti ostaju na istoj niskoj razini (0,338 za Hrvate/hrvatska sela i 0,351 za Srbe/srpska sela).

6. Iz analize utjecaja faktora etničke diferencijacije na procjenu udaljenosti isključili smo doseljenike, budući da su lokalni kulturni stereotipi "fenomeni dugog trajanja” (Džambo, 1999:118).

7. Usput treba reći da je, kako izgleda, takva "etnička strukturiranost" komunikacije slabije izražena u formalnijoj komunikaciji kod odrasle populacije. Iz odgovora na pitanje "Gdje tvoji roditelji kupuju namirnice?” možemo vidjeti da oni roditelji koji ne odlaze po namirnice u grad (Petrinju ili Sisak) obično kupuju u Jabukovcu ili Banskom Grabovcu, bez obzira na njihovu etničku pripadnost. Tu ipak treba primijetiti da u oba sela, većinski srpska prije rata, danas žive i Hrvati iz $\mathrm{BiH}$ i Vojvodine te Hrvati romskog podrijetla, pa je moguće da ih upravo današnja mješovitost etničke strukture čini prikladnim lokalnim trgovačkim centrima za sve.

\section{LITERATURA}

Ajduković D. i Bistrović E, 1987: Prilog grafičkoj metodi istraživanja kognitivnih prostornih mapa, Revija za psihologiju 17 (1-2), 67-80.

Bailly A. S., MacCabe Ch. and Saarinen Th., 1995: Images of Francophone Countries and Francophone Images of the World, Geographica Helvetica 1, 3-11.

Brown M. and Broadway M. J., 1981: The Cognitive Maps of Adolescents: Confusion about Inter-town Distances, The Professional Geographer 33 (3), 315-325.

Čačić-Kumpes, J. and Nejašmić I., 2001: Social Changes, Migration and Ethnic Structure: Case Study of Petrinja (Croatia), Društvena istraživanja, 10 (1-2), 253-277.

Gould P. and White R., 1974: Mental Maps, Penguin, New York.

Downs R.M., 1981: Maps and Metaphors, The Professional Geographer 33 (3), 287-293.

Downs R. and Stea D., 1973: Cognitive Maps and Spatial Behavior: Process and Products, in: Downs R. and Stea D. (eds.) Image and Environment, Aldine Publishing Co., Chicago, 8-26.

Džambo, J. 1999: Maledicta ethnica. O nacionalnim stereotipima i verbalnoj agresiji, u I. Pranjković, I. i Jeličić S. (ur.) Zbornik u čast dr. fra Ignacija Gavrana, Udruga đaka franjevačke klasične gimnazije, Zagreb.

Ewing, G.O., 1981: On the Sensitivity of Conclusions About the Bases of Cognitive Distance, The Professional Geographer 33 (3), 311-314. 
Hart R., 1984: The Geography of Children and Children's Geographies, in: Saarinen Th.,

Seamon D. and Sell J. L. (eds.) Environmental Perception and Behavior. The University of Chicago, Department of Geography, Research paper no. 209., 99-129.

Kitchin R. and Blades M, 2002: The Cognition of Geographic Space, I. B.Tauris Publishers, London and New York.

Kitchin R. M. and Fotheringham A.S., 1997: Aggregation Issues in Cognitive Mappimg, Professional Geographer 49 (3), 269-280.

Lloyd R., 1989: Cognitive Maps: Encoding and Decoding Information, Annals of the Association of American Geographers 79 (1), 101-124.

Lynch K., 1960: The Image of the City, The MIT Press, Cambridge.

Mišetić, R., 2002: Utjecaj prisilnih migracija na promjenu biološkog sastava stanovništva - primjer Sisačkomoslavačke županije, Migracijske i etničke teme 18 (4), 307-317.

Pacione M., 1978: Information and Morphology in Cognitive Map, Trans. Inst. Brit. Geogr. 3 (4), 548-568.

Piaget J. and Inhelder B., 1967: The Child's Conception of Space, New York, Norton Libraty.

Portugali J. and Haken H., 1992: Synergetics and Cognitive Maps, Geoforum 23, 111-130.

Tolman E.C., 1948: Cognitive Maps in Rats and Men, Psichological Review, 55, 189-208.

Tuan Yi-Fu, 1975: Images and Mental Maps, Annals of the Association of American Geographers 65 (2), 205-213.

Tverski B., 2000: Levels and Structure of Spatial Knowledge, in: Kitchin R. and Freundschuh S. (eds.) Cognitive Mapping. Past, Present and Future, Routledge, London and New York, 24-43.

Uttal D.H. and Tan L.S. 2000: Cognitive mapping in Childhood, in: Kitchin R. and Freundschuh S. (eds.) Cognitive Mapping. Past, Present and Future, Routledge, London and New York, 147-165.

Živić, D., 2000: Demografski okvir i posljedice rata protiv Hrvatske (1991-1997), Doktorska disertacija, PMF, Zagreb.

SUMMARY

\section{Cognitive Maps in a Post-Conflict Situation: the Image of One's Own Region among Pupils in Jabukovac Elementary School (Banovina)}

\section{Laura Šakaja}

This paper examines cognitive maps among pupils in higher grades of the elementary school in the village of Jabukovac (in the Banovina region of Croatia). Analysis of these cognitive maps was based on spatial representations of the pupils' own environment, i.e. on sketch-maps of their area drawn by the respondents themselves, as well as on the respondents' answers to questions in regard to their home area.

The study had several aims: a) to contribute to a greater knowledge of cognitive maps; b) to reduce, at least partially, the lack of scientific research on cognitive maps in Croatia; c) to research the possible influence of post-conflict situations on the spatial perceptions of children, by examining 
Laura Šakaja - Kognitivne karte i post-konfliktno stanje:

slika vlastitoga kraja učenika osnovne škole Jabukovac (Banovina)

the cognitive maps of 11-16 year-old pupils living in the former UNPA zones (United Nations Protected Areas) of Croatia.

During the research an attempt was made to answer the following questions: How is spatial structure shaped in the perception of children? How do children perceive distance and directions? What elements of the geographical setting are important to them, and which do they neglect? What is remembered and serves as an orienteer, and what is forgotten? How are individual aspects of one's own milieu valorised? Do the children's cognitive maps reveal traces of the bloody conflict that recently took place in this area?

By applying quantitative methods, i.e. by analysing hand-drawn sketch-maps, this paper tested several prepositions on the factors transforming spatial relationships in the process of creating spatial images. The following was shown:

1. Direct knowledge makes locations more alive in one's consciousness:

- first, individual direct experience influences selectivity in the transfer of information into cognitive images;

- second, direct experience influences maps in accordance with the so-called magnifying glass effect, which means that cognitive maps, when they adapt in order to incorporate greater knowledge of a certain region, "stretch" the image of such places (regions).

2. Roads and routs are extremely important elements in the formation of cognitive maps. They also influence the selection of elements and the deformation of relationships in the psychological process of creating mental images:

- sketch-maps more often include settlements through which the respondents pass every day, than settlements outside of their daily travel routs;

- distance between settlements is underestimated (shortened) if the settlements are located along frequent roads;

- locations along roads are perceived as settlements in a straight-line series, despite road curvatures;

- cognitive maps are skewed towards key routs of daily communication, and in several cases the entire cognitive map is perceived from the perspective of one's daily travel rout (movement), and not from the perspective of the settlement.

This study confirmed some already well-known regularities in cognitive maps:

- rounding out all directions towards the major directions - as a form of simplification in the process of psychological transfer;

- variations in the degree of distortion: overestimation of the distance to near places and underestimation of the distance to remote places.

The approach in this research was based on the belief that quantitative methods are not sufficient to make conclusions about actual mental representations of the external setting, due to the fact that such methods focus on spatial relations and disregard other aspects of the environment. Therefore, to supplement our knowledge of the complex ways of experiencing one's own geographical setting, we also applied qualitative methods in analysing responses to open questionnaire items. Reconstructing these responses on informal geographical knowledge of one's home region, we arrived at some conclusions in regard to the parameters through which it is experienced.

- size, structure and morphology are important parameters around which informal knowledge about a settlement is grouped;

- for children, the most important functional elements of a settlement are schools, shops, places of entertainment (playgrounds, stadiums) and churches; 
- monuments are also important signs of recognition of a place, but they are perceived as elements of the landscape, i.e. devoid of their ideological "weight";

- people are one of the most important parameters through which a settlement is experienced. Informal knowledge of the human aspect of a location is based: a) on a knowledge of the general socio-demographic traits of the inhabitants, b) on stereotypes about the inhabitants of a settlement, and c) on personal relations with individuals.

Although studies by some authors have shown that ethnic culturalism may act as a filter in the transfer of spatial relations onto cognitive maps, the quantitative part of our study showed that ethnic relations did not at all influence purely spatial relations: the respondents' sketch-maps did not show any differences in regard to the ethnic aspect. However, culturalism did appear in the textual responses. Namely, traces of ethnic culturalism show themselves in the fact that the play area is limited only to settlements of the same predominant ethnic affiliation. The fact that the young respondents avoided all comments in regard to sensitive ethnic issues, the war and fear, could be also interpreted as a consequence of the recent interethnic conflict (the terms Serb, Croat, Serb village, Croat villages were never mentioned): omissions, passing over in silence and empty places, so called shadows are regarded even more expressive than the text itself in the deconstruction techniques of text interpretation.

Much more open expression was given to other (non-ethnic) aspects of the region, likewise connected to its post-conflict character. The post-war drop in the population of a region that had already been subject to depopulation had a major effect on the lives of its children: namely, playmates and opportunities for communication between children have become a rare privilege. For this reason, among respondents, loneliness is a pronounced aspect in their experiences of their own region.

Destruction of the previous infrastructure and the insufficiency and non-functionality of the new one have determined tones of nostalgia in the respondents' experiences of their home region that one would not expect among children (of the type, "once there was..."). Landmarks are often facilities that no longer exist - the old school, the former fire-brigade lodge, etc.

The poor functionality of communal services has resulted in a state of neglectedness, in the emergence of uncontrolled dumping gounds, in the pollution of streams and rivers, which all increases caution and fear, and in some areas reduces the already limited zone of free movement, due to the possibility of remaining landmines.

The experiences of war, expulsion and refugee life have obviously taught children to value their own home. Hence the degree of contentment with their own region was quite high among the respondents. Yet the somewhat different life circumstances of the three population groups in the Banovina region (local Croats, local Serbs and Croat immigrants from Bosnia and Herzegovina) have brought about certain differences in their valorisation of diverse aspects of their region. Serb returnees perceive their region as very secure, but also as quite devastated. Croat returnees are the most satisfied with life in the region, which they see as friendly, renovated and alive, whereas Croat immigrants from Bosnia and Herzegovina and Vojvodina are the most dissatisfied and perceive the region as dull, gloomy, less secure and less friendly.

Laura Šakaja, dr.sc. docent Geografski odsjek, Prirodoslovno-matematički fakultet, Marulićev trg 19, 10000 Zagreb, Hrvatska/Croatia e-mail: lsakaja@geog.pmf.hr 